\title{
CYCLE TOURISM IN RURAL AREAS: PROMOTING A RAIL TRAIL NETWORK IN ANDALUSIA, SPAIN
}

\author{
Reyes González-Relaño* \\ University of Seville \\ https://orcid.org/0000-0003-1560-2779 \\ Jesús Ventura-Fernández* \\ University of Seville \\ https://orcid.org/0000-0002-8271-1011 \\ Gustavo Antonio Contreras-Cabrera* \\ University of Seville \\ https://orcid.org/0000-0003-2903-0484
}

\begin{abstract}
Rail trails are non-motorised routes resulting from the conversion of disused railway lines, geared towards cycle tourism and other leisure activities. This paper seeks to highlight the potentialities and shortcomings of rail trails in Andalusia. A diagnosis is made through a SWOT matrix, with information from the management bodies and a coherent planning is applied. The results enable proposals intended to remedy the shortcomings detected and create an effective rail trail network in Andalusia, managed in a coordinated fashion and internationally comparable with regard to public usage.
\end{abstract}

Keywords: Non-motorised routes; rail trails; cycle tourism; strategic planning; logical framework approach; Andalusia (Spain).

\section{Cicloturismo en espacios rurales: promoviendo una red de vías verdes en Andalucía}

\section{RESUMEN}

Las vías verdes son itinerarios no motorizados resultado de adaptar líneas ferroviarias en desuso al cicloturismo y otras actividades de ocio. El artículo resalta las potencialidades

Fecha de recepción: 20 de marzo de 2020.

Fecha de aceptación: 27 de noviembre de 2020.

* Department of Physical Geography and Regional Geographical Analysis. C/ María de Padilla, s/n. 41004 SEVILLA (Spain).E-mail: rgrelano@us.es; jventura@us.es; gcontreras@us.es 
y deficiencias de estas rutas en Andalucía. Con información procedente de sus órganos de gestión, se realiza el diagnóstico con una matriz DAFO como base para abordar la planificación mediante objetivos. Se proponen acciones para resolver los problemas detectados y crear una red de vías verdes eficiente para Andalucía, gestionada de manera coordinada y comparable internacionalmente con respecto a su uso público.

Palabras clave: itinerarios no motorizados; vías verdes; cicloturismo; planificación estratégica; enfoque del Marco Lógico; Andalucía (España).

\section{INTRODUCTION}

Rail trails are old out-of-service railway lines, rehabilitated as non-motorised routes suitable for outdoor physical exercise and active tourism, mainly cycle touring and hiking (European Greenways Association, 2000; Taylor, 2015; Eizaguirre-Iribar et al., 2016). Although there has been an evident increase in the number and popularity of these routes, and despite their clearly growing importance as recreational and tourism assets (Lamont, 2009), there have been very few scientific studies focused on them to date (Ritchie et al., 2010; Senes et al., 2017). Indeed, there has still been little in-depth analysis of different aspects of the tourism experience or study of the impact of the use of this resource on the local communities involved (Abildso et al., 2012) and on visitors (Bichis-Lupas and Moisey, 2001; Oswald Beiler et al., 2015). This is so despite the fact that rail trails are currently being converted into infrastructures that interconnect the territory and influence its potential for development (Serra, 2016). They constitute an important resource for tourism (Reis and Jellum, 2012; Reis et al.,2014) and should be understood as complex systems of relationships created within the territory, which require thorough examination (Eizaguirre-Iribar and Grijalba, 2020).

In this respect, authors such as Manton et al. (2016) or Scott et al. (2010), who undertook studies on non-motorised recreation, indicate that rail trails help to promote ideals of rural sustainability. When any non-polluting means of transport is used on these routes, this contributes to environmental conservation, promotes healthier lifestyles (Litman, 2010) and favours both the recovery of railway heritage and endogenous development (Lumsdon et al., 2004; Fundación de los Ferrocarriles Españoles (FFE) and Universidad de Sevilla, 2014). These characteristics combine to create a tourist attraction for the environmentally aware and, in turn, improve the quality of the product, converting it into a sustainable tourism experience (Lumsdon, 2000; Serra, 2016). The connection with the environment and the landscape by means of a physically active recreational activity adds another dimension to the tourism experience, which often leads to a positive sensation of wellbeing, health and reinforced social ties (Green, 2009; Mundet and Coenders, 2010).

Since the first trail, the $88 \mathrm{~km}$ Illinois Prairie Path, was inaugurated in the 1960s (Quattrone et al.,2018), there have been many successful rail trail experiences. These have been especially noteworthy in Australia, New Zealand, the United States, the United Kingdom, France, Germany and Italy, among other countries (Reis et al., 2014; Senes et al., 2017; 
Abildso et al., 2018). In Europe, it is also necessary to highlight the case of Belgium, where the national railway system handed over almost 1,000 km of disused lines for the creation of a rail trail network in 1997. This was the example followed by Spain (Mundet and Coenders, 2010), which now has more than 2,900 kilometres of rail trails in operation (along 121 routes). In the case at hand, the Autonomous Community of Andalusia has 27 of these trails, whose combined length is almost $600 \mathrm{~km}$ (Annex 1).This accounts for around $21 \%$ of the Spanish total, whereas Andalusia only occupies $17 \%$ of the total area of the country. This fact, the relatively high quantity of converted rail trails compared with the country as a whole, inspired the choice of Andalusia as the geographical area of analysis for this paper. Furthermore, there is still an enormous amount of disused railway lines in this region that could potentially be converted into rail trails. This resource, unlike in other regions, is favoured by the latitudinal disposition of its relief and he prevailing warm Mediterranean climate, as well as the important legacy of cultural and natural heritage, and the great weight of the tourism sector in its production structure, although in need of greater diversification. Thus, Andalusia has great potential for bicycle tourism. Furthermore, two of the three European cycle tourism routes of the EuroVelo ${ }^{1}$ network in Spain run through Andalusian territory: the Atlantic Coast Route, which passes through the province of Huelva to connect with the Portuguese Algarve; and the Mediterranean Route, which runs close to the Andalusian Mediterranean coast until it ends in the city of Cádiz (Lumsdon et al., 2009; ECF, 2020). Hence, the Andalusian rail trails constitute an excellent resource on which to base cycle tourism routes with considerable guarantees of success (Ventura-Fernández and Gavira-Narváez, 2016).

Given this context, this paper aims to analyse and assess the current situation of the set of Andalusian rail trails and put forward strategic proposals to improve their use in general and for tourism in particular. Specifically, a diagnosis of the rail trails is made in order to subsequently design a tourism development strategy that combines taking opportunities to correct deficiencies and imbalances observed with exploiting the full potential of these trails. To this end, after establishing the corresponding theoretical framework and reviewing the sectoral and territorial planning which, one way or another, affects the matter at hand, an overall diagnosis is made based on identifying the strengths, weaknesses, opportunities and threats (SWOT) of the 27 rail trails, on the basis of primary information obtained from the respective management bodies.

By applying the logical framework approach, the following result is obtained: a) a diagnostic tree linked to the use and enjoyment of rail trails by tourists, which subsequently serves as a basis for b) the preparation of an objectives tree that is strategic, direct and consistent with three key thematic areas. This paper thus aims to provide guidelines for action for planners and administrators to help make the most of these assets and thereby contribute to the pursuit of sustainable tourism development in rural areas.

1 EuroVelo is a network of long-distance cycling routes under the coordination of the European Cyclists' Federation (ECF, 2020), which will make it possible to tour the whole of Europe. Its completion is envisaged for 2020 , and it began with the dual function of being used and enjoyed by long-distance cycle tourists and by the inhabitants of the territories it passes through. 


\section{RAIL TRAILS, REVITALISING RURAL AREAS AND CYCLE TOURISM: A SHARED SPACE}

There is scientific consensus on the potential of old disused railway lines as possible non-motorised routes (Moore and Shafer, 2001; Reis and Jellum, 2012; Taylor, 2015; Quattrone et al., 2018). Likewise, the abandoned stations and other structures (tunnels, viaducts, etc.) linked to railways provide available space for new activities associated with rural development and heritage regeneration processes (Senes et al., 2017). In fact, users of rail trails do not only use them for sporting pursuits, but also for tourism activities based on a commitment to, and appreciation of, the landscape and the natural area that the routes pass through, thereby increasing the quality of the tourism experience (Bell, 2018).

Furthermore, the tourism development of these infrastructures entails the aforementioned transformation of old stations and stopping places into eating places, reception areas, information points and bicycle maintenance centres, thereby favouring the appearance of new recreational and catering activities (Guerrieri and Ticali, 2012; Ferretti and Degioanni, 2017). Thus, their conversion and implementation are an important source of job creation (FFE, 2011) and they become a driver for growth in local economies (Di Ruocco et al., 2017). Moreover, the rehabilitation, enhancement and use of old viaducts, tunnels and stations contribute towards enriching the visitor experience (Willard and Beeton, 2012). Such heritage assets are protected in order to provide enjoyment for tourists, but this also helps to preserve the history of rural communities (McKercher, 2001).

Due to their particular railway origin, rail trails have optimal conditions of accessibility, comfort and safety (Evenson et al., 2005), thereby guaranteeing their availability for all types of users, including people with reduced mobility (Plataforma Representativa Estatal de Personas con Discapacidad Física and FFE, 2017). Consequently, these trails have been transformed into popular products for those who seek recreational activities, as their gentle gradients make it possible for a wide range of users to access these routes (Beeton, 2006; Reis and Jellum, 2012; Gibson and Chang, 2017): cyclists, hikers and also people with certain mobility difficulties (the old, pregnant women, etc.), who need to exercise moderately (Van Blarcom and Janmaat, 2013).

In this context, one of the main activities that rail trails are geared towards is cycle tourism, that is, recreational visits that involve leisure cycling as a fundamental and important part of the tourist's reason for making the trip (Sustrans, 1999). A report on the economic impact of cycle tourism in Europe (El impacto económico del cicloturismo en Europa: FFE and Universidad de Sevilla, 2014) notes that a cycle tourist spends an average of $€ 57.08$ a day and a total of $€ 439$ per trip, and that, for each euro invested in cycling infrastructure, $€ 19$ are recouped. These data reflect the economic benefits generated by rail trails and associated activities in their area of influence: localities that they pass through or nearby (Ventura-Fernández et al.,2017). This is especially the case for longer trails (Downward et al., 2009), as touring cyclists travel an average of $60 \mathrm{~km}$ a day, compared with $41 \mathrm{~km}$ for cycle tourists who do not spend the night away (Lumsdon et al., 2009).

In relation to this activity, the success of these trails is largely explained by the separation that exists between the route they follow and the ordinary road network, with very few intersections with the road infrastructure (Parkin et al., 2007). Moreover, as the trails 
tend to be long, straight and sufficiently wide, they facilitate the co-existence of different non-motorised uses, predominantly cycle tourism and hiking. Additionally, these routes traditionally run through rural areas, through land of great natural and scenic value, usually close to protected areas (Moral, 2016), precisely where motorised traffic cannot reach. In Spain, they frequently pass through protected natural areas, land linked to the Natura 2000 network and geoparks, although to date there has not been any specific integration and exploitation of this natural heritage in rail trail settings (Martín, 2018). In the case of Spain, more than $91 \%$ of rail trails have at least one protected natural area at less than $5 \mathrm{~km}$ from some point on the route and, specifically in the case of Andalusia, 24 out of 27 (Figure 1) are within this distance from natural areas under some type of protection. On the basis of these characteristics, some authors (Luque-Valle and Rebollo-Rico, 2012; Rodríguez Moreno, 2016) have gone so far as to define rail trails as the sports facilities of the future, as they facilitate doing sport in areas of great natural value (Kaczynski and Henderson, 2007), enabling cycle tourism to be reborn as a green tourism activity.

Furthermore, the close connection between railway tracks and the history of the economic and social development of the rural areas they run through adds a heritage component to these trails, as demonstrated in the studies of Moore and Shafer (2001). These routes are often associated with stories of struggles and successes, which should be recovered and transmitted to the tourists who travel along them. The tourism product therefore takes on the cultural importance of the route (Timothy and Boyd, 2014), providing a cultural tourism experience for visitors that includes "slow" practices and reinforces the significance of the area's own history and associated values and lifestyles (Dickinson and Lumsdon, 2010).

Another significant aspect highlighted by some authors is that rail trails help to connect members of the local community with tourists through the use of a shared leisure space (Baker, 2001; Abildso et al., 2018). They are, therefore, an appropriate scenario for strengthening community ties and relating to different communities (Spencer, 2013). However, this fact entails the need for public-private cooperation at different levels (local and regional, at least) (Davies and Weston, 2014). Hence, rail trails are resources that not only unite different geographical environments, but also bring together distinct socio-political spheres, affecting different actors who pursue heterogeneous objectives (Cebrián, 2011; Spenser, 2013). Decision making in this context may be complicated, basically due to the different points of view of the actors involved and the uncertainty added by distinct time horizons (De Marchi et al., 2016). In view of this, it is necessary for decision making to be part of a process that is capable of incorporating diverse perspectives in the interests of the greatest possible consensus. 


\section{Figure 1}

RAIL TRAILS IN ANDALUSIA AND PROTECTED NATURAL AREAS

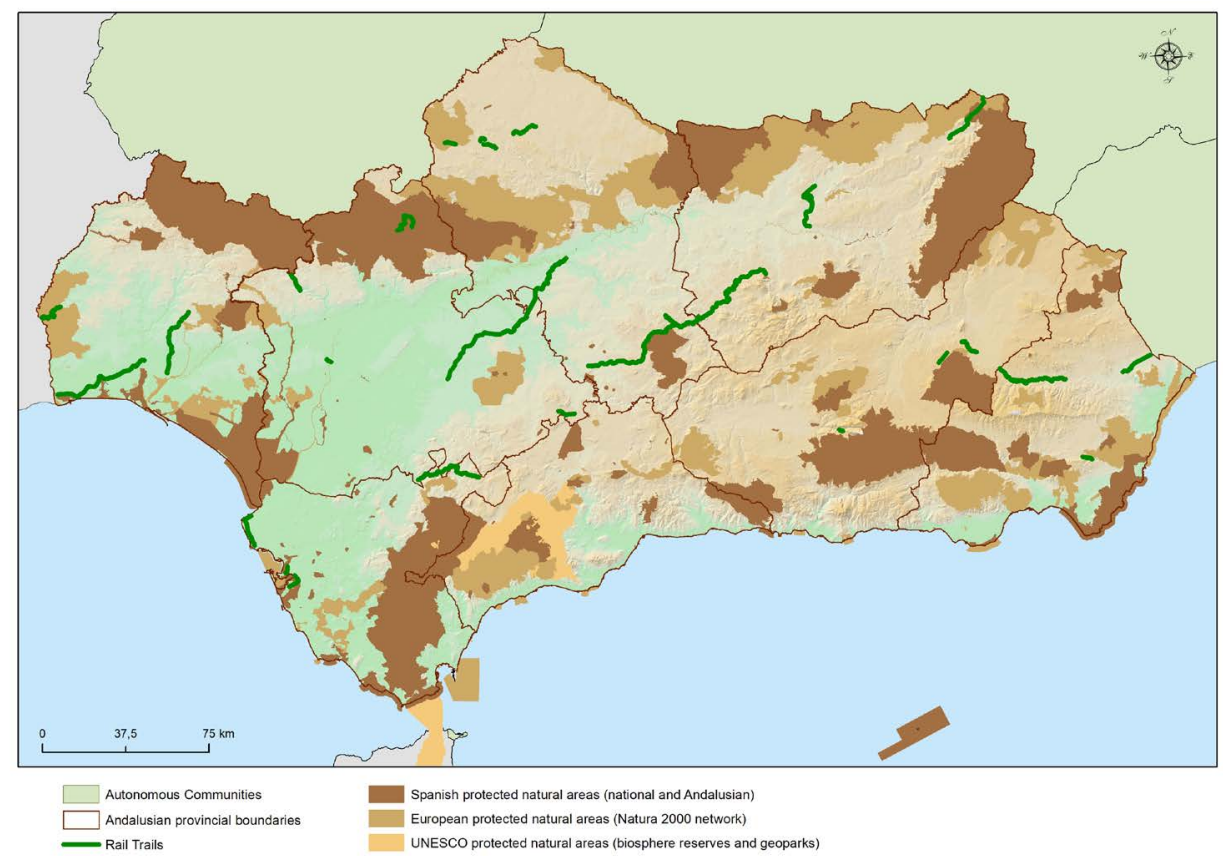

Source: own preparation.

\section{THE INSTITUTIONAL VIEW OF RAIL TRAILS IN ANDALUSIA}

One of the most important aspects to bear in mind when making a diagnosis and strategic proposals for action is the public administration approach to this type of trails. In the specific area under study here, Andalusia, there are no less than four regional bodies which, in one way or another, and with a variety of approaches, intervene with respect to rail trails (currently assigned to 3 regional ministries: Tourism and other matters; Development, Infrastructure and Territorial Planning; andAgriculture, Livestock, Fisheries and Sustainable Development). This is explained by the transversal nature of these infrastructures, as in practice they are dealt with from the perspective of territorial connectivity, their implications for sustainable mobility, as a resource to boost tourism activity and as an instrument to revitalise rural communities starting from the areas of socio-economic influence generated by the rail trails ${ }^{2}$. In the case of Andalusia, and as can be seen in Figure 2, the different areas of socio-economic influence of rail trails add up to more

2 By analogy with the concept of area of socio-economic influence of protected natural areas, in this case the group of municipalities that have a rail trail passing through their territory is taken into consideration, thus forming a territorial zone that is subject to socio-economic development initiatives (Alburquerque \& Delgadillo, 2009), including the promotion of sustainable mobility, in accordance with the rail trail present in the zone. 
than $11,000 \mathrm{~km} 2$ and house a population of around 2 million inhabitants (Annex 1). This accounts for $12.66 \%$ of the area of the region (of a total of over $87,000 \mathrm{~km}^{2}$ ) and 22.99 $\%$ of the population (of almost 8.5 million inhabitants).

In this context, the competent body in matters of Tourism at regional level deals with the promotion of rail trails and their use as a way to achieve complementarity between tourism segments. Specifically, it indicates that cycle tourism could become one of the emerging micro-products and micro-segments to be developed within Andalusian territory. Thus, from an analysis of the documents of sectoral planning (General Sustainable Tourism Plan, Tourism Promotion Master Plan, Strategies for the Management of Tourism Seasonality, Comprehensive Strategy for the Promotion of Sustainable Inland Tourism), it is possible to glean an assessment of rail trails as a tourism product that may stimulate the territory under the influence of these routes. To this end, the competent regional body indicates the need to carry out an appraisal of both the trails themselves and the requirements for essential facilities for their tourism development and promotion.

Meanwhile, for the body responsible for mobility in Andalusia, sustainable mobility, active tourism and, specifically, cycle tourism, represent a common denominator in the case of rail trails. Consequently, actions are underway to complete the design of a dense network of non-motorised routes throughout the Autonomous Community, subject to the maintenance of good connectivity between these routes. In the Andalusian Bicycle Plan (Plan Andaluz de la Bicicleta; PAB), drawn up for the period 2014-2020, 8 axes are established criss-crossing the regional territory with a vocation geared preferably towards leisure, sport and active tourism. They add up to a total of $3,080 \mathrm{~km}$, and incorporate 359 $\mathrm{km}$ of rail trails (almost $12 \%$ of the regional routes of the PAB). The fundamental goals of this plan converge in two complementary ideas. On the one hand, the intention to contribute to the process of change of the mobility model, orienting it towards a greater degree of environmental, social and economic sustainability, and on the other hand, introducing the bicycle as an essential element of this change.

Both of these intentions are fully compatible with the idea of rail trails in Andalusia, and the trails with the capacity and suitability to form part of the different routes proposed in the PAB could be incorporated at three territorial levels. First, at regional level, via the creation of a network of cycle paths for leisure, tourism and sport in line with the current use of rail trails, thereby enabling an adequate territorial organisation, and even future extensions as more sections of disused railway lines are converted and prepared. Second, in metropolitan environments, via the integration of bicycles into strategies for developing intermodal systems through the inclusion of certain rail trails. Third, in urban areas, by supporting the creation of cycle path networks and the introduction of complementary services, adapting existing routes and open spaces, including the urban sections of rail trails that are compatible with this proposal. 


\section{Figure 2 \\ SPATIAL DELIMITATION OF MUNICIPALITIES AFFECTED BY THE RAIL TRAILS IN ANDALUSIA}

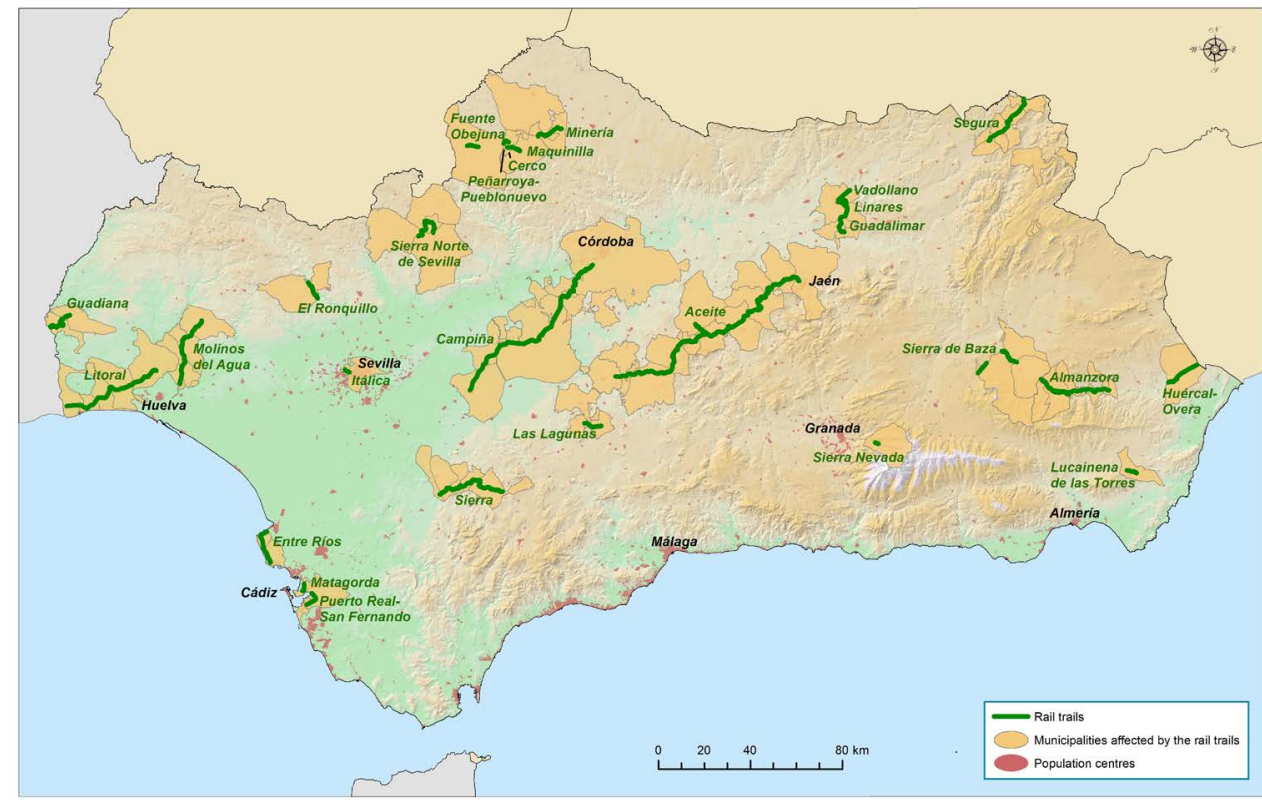

Source: own preparation.

Moreover, it is necessary to point out that there is also interest in disused railway infrastructure from the perspective of the Spatial Planning, even in the case of some trails that never became operational, such as the Jerez-Almargen route (Rincón-Millán, 2013). Thus, at the sub-regional level of land-use planning, attempts to take advantage of these abandoned routes in order to improve connectivity on this scale are underway, as can be seen in the case of the Bahía de Cádiz-Jerez route, currently under review.

In parallel, from the perspective of rural development, the Law on the Sustainable Development of the Rural Environment (LDSMR) of 2007 was implemented via a Royal Decree of 2010 , by means of which the establishment of so-called "zone plans" was activated, 11 of them in the case of Andalusia during the period 2012-2016 (Ministry of Agriculture, Fisheries and Food, 2020). Its application in the region enabled the socio-economic revitalisation of large rural areas under the criterion of environmental sustainability, possibly affecting $79.6 \%$ of Andalusian territory according to the initial delimitation of rural zones that could potentially benefit, comprising the aggregation of sparsely populated municipalities. Structured actions would be applied to these zones according to four programmatic axes. The set of proposals included in the Axis of infrastructures and basic amenities is of special interest. These proposals are centred on the adaptation of public thoroughfares, abandoned railway lines and other types of underused or disused paths, 
such as tracks for non-motorised use, for the purposes of leisure in nature and recreational, sporting and tourism activities. They also include works for the new construction, renovation or improvement of transport routes, including networks of public paths and trails of tourism or cultural interest.

\section{Figure 3}

\section{RAIL TRAILS AND RURAL AREAS TO BE REVITALISEDIN ANDALUSIA}

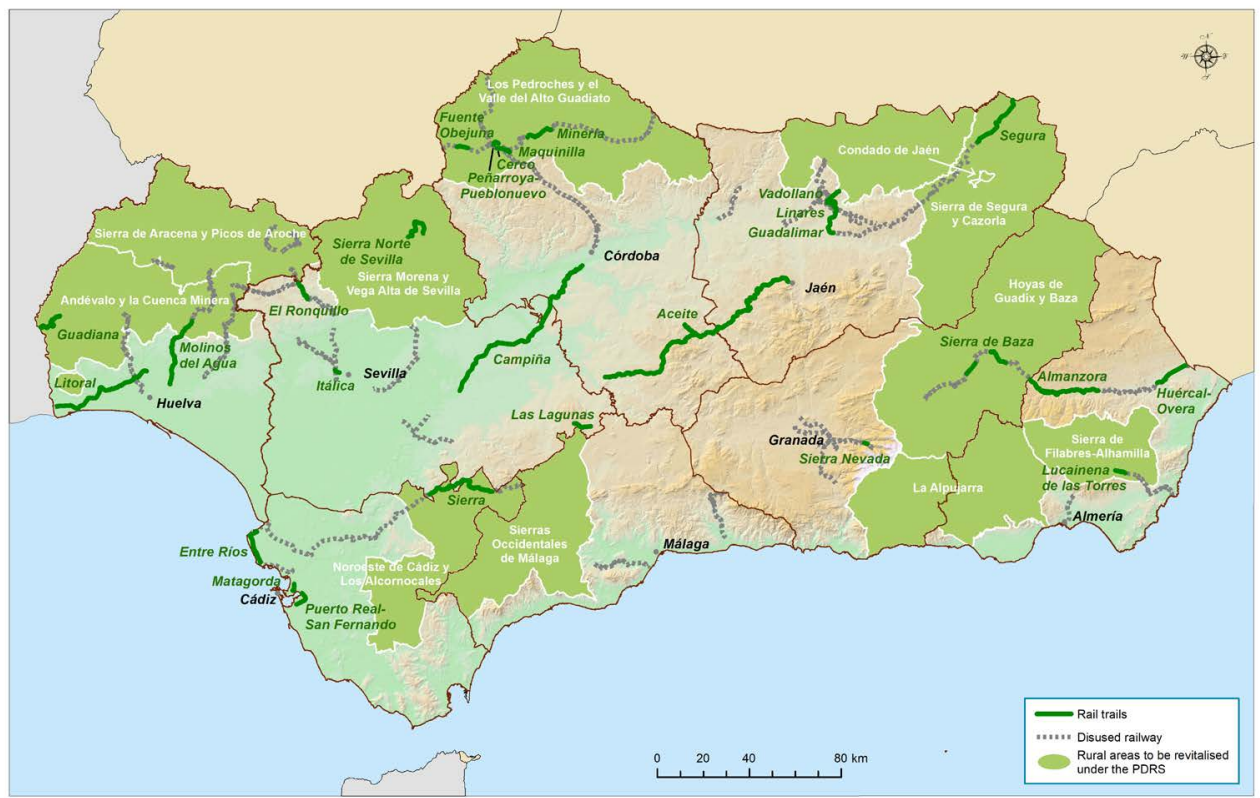

Source: own preparation.

During the period of implementation of the Sustainable Rural Development Programme (PDRS), and through the so-called "rural zone plans" for Andalusia (2012-2016), 311 municipalities were involved in the eleven Andalusian areas declared as priority intervention zones, with a population of approximately 716,000 inhabitants (around $8.5 \%$ of the population of Andalusia). More specifically, 8 rail trails were located in 6 of these 11 declared zones; a relevant fact given the opportunities the PDRS provides for the tourism promotion of this network of non-motorised routes via their rehabilitation and fostering as territorial resources. These zones and their current rail trails were the following: Sierra de Filabres-Alhamilla (Almería): Lucainena de las Torres; Noreste de Cádiz y Los Alcornocales (Cádiz): La Sierra; Los Pedroches y el Valle del Alto Guadiato (Córdoba): La Maquinilla, Peñarroya-Pueblonuevo, Cerco Minería and Fuente Obejuna; Hoyas de Guadix y Baza (Granada): Sierra de Baza; Andévalo and Cuenca Minera (Huelva): Guadiana and Molinos del Agua; and Sierra Morena y Vega Alta de Sevilla (Seville): Sierra Norte de Sevilla (Ministerio de Agricultura, Pesca y Alimentación, 2020). 
Nevertheless, it is currently possible to envisage the possibility of giving renewed impetus to the PDRS, thereby facilitating the revitalisation of Andalusian rural areas through the use of these infrastructures and amenities in a balanced manner throughout the entire region. This would entail focusing especially on the conversion of new sections of disused railway lines into rail trails and working on the maintenance, safety and visibility of these trails in order to guarantee their development and use for cycle tourism. The state-level PDRS 2014-2020 is currently still in force, as well as its implementation in Andalusia during the same period.

In this respect, the cartographic expression of the territorial coincidence between the rural areas to be revitalized, rail trails and disused railway lines is revealing (Figure 3), as it clearly demonstrates the aspects to be considered in future strategic proposals for the network. It may be considered as an example for programming measures that could potentially benefit from the resources provided by the PDRS, and it serves to identify high priority rural areas for socio-economic revitalisation. Moreover, the dynamic character of the rail trail network due to possibilities of incorporating more disused railway lines should not be overlooked.

\section{RESEARCH METHODS}

In order to achieve the proposed objective, that is, the formulation of a planning proposal by means of strategic goals and lines of action, it is necessary, as a first step, to have in-depth knowledge of the initial situation and identify the current state of rail trails in Andalusia. In this respect, the need to obtain primary information from representatives of the management bodies of Andalusian rail trails was recognised, all of whom are linked to the Local Administration at different levels and in different ways. In order to undertake this consultation, a background document was drawn up on the basis of work carried out in 2015 within the context of the project entitled "Creation of a platform of territorial information and technological support of rail trails in Andalusia. Citizens' access to the information society". This document initially contained demographic, social, economic and environmental aspects, although to achieve the objectives of this study, the most significant opinions and assessments which, directly or indirectly, affect the development of tourism activity linked to the use of rail trails, were compiled. These assessments, or perceptions, were taken by the researchers as a starting point and consist of 16 possible types of strengths, weaknesses, opportunities and threats, subject to the triple possibility of being verified, rejected or reformulated by those management bodies responsible for their implementation.

The process of consulting the 27 management bodies was carried out in two stages. The first stage was in 2015, when there were 23 rail trails in Andalusia, with a 100\% response obtained to questionnaires sent via e-mail, along with a process of verification of results undertaken by the Spanish Railways Foundation (Fundación de los Ferrocarriles Españoles), the body responsible for promoting the "Rail Trails" programme at national level, in support of the work of Andalusian Geographical Studies Research Group. The second stage was during the second half of 2018, when a process of updating and including new trails was undertaken, thus arriving at the present 27 trails, and obtaining the assessment of 25 management bodies by means of personal consultation. This latest updating of the study 
also incorporated opinions based on new strengths, weaknesses, opportunities and threats detected for these routes in relation to their fostering, use and tourism promotion (Annex 2).

After receiving all these contributions, an evaluation was conducted by means of an analysis of coincidences in the assessments made. The model followed is based on the allocation of a qualitative weighting, in accordance with the percentage of recurrences in the replies of the management bodies (García et al., 2004; Abascal and Grande, 2005; Ramírez, 2009; Astigarraga, 2016). The recurrence classification applied was Low (insignificant, with coincidence of replies under $33.3 \%$ of representatives), Medium (indicative, between $33.3 \%$ and $66.6 \%$ ) and High (consensus, values over 66.6\%). The replies with a low level of backing were rejected, as those chosen by less than a third of the management bodies were considered to be poorly representative. The final result of this process was a SWOT table of aspects linked to tourism activity for Andalusian rail trails as a whole.

On the basis of the initial SWOT, derived from the processing and verification of the assessments obtained and the subsequent updating of results, a diagnostic tree was constructed with the main problems, needs and expectations of the entire set of these routes. The composition of the diagnostic tree created consists of three identification levels linked by a causal relationship. This form of diagnosis shows a clear ascending nature in the setting of contents, going from specific (level 1) to global (level 3). Level 1 includes different relevant aspects, arising from the SWOT information and the personal interviews conducted, disaggregated into three thematic areas, which correspond to the use and exploitation of the rail trails, the socio-economic development of the affected territories and the management of the different routes. Level 2 of the diagnostic tree corresponds to the three key effects deriving from each of the aforementioned thematic areas. Finally, the postulation of a general conflict (level 3) is arrived at, related to the main problem to be resolved.

Subsequently, corresponding to the diagnostic tree, an objectives tree was created, establishing guidelines for strategic action that are consistent with the logical framework approach methodology and the planning formula (Roduner et al., 2008; Couillard et al., 2009; Aldunate and Córdoba, 2011; Las Casas, and Scorza, 2016). Thus, taking an overall aim as reference, which could be achieved with the reinforcement of other development objectives, it is possible to construct a strategy (Godet and Durance, 2009) for boosting tourism that eliminates or reduces the negative aspects of the diagnosed reality (Valls and Neves, 2014), as well as incorporating those potentialities present in the set of rail trails. In this respect, a three-level scheme of objectives is established, starting with the formulation of a general objective (level 3), attainable via three strategic objectives (level 2) that respond to the three key effects of the three thematic areas diagnosed previously. Finally, the tree is completed by setting 9 specific objectives (level 1), as a mirror response to the earlier 9 relevant aspects.

According to this logical framework methodology, often used by authors and international bodies for planning (Gasper, 2000; Bakewell and Garbutt, 2005), the strategic response given to the initial diagnosis gives coherence to the cause-effect relationship examined, providing the managers of each of these routes with tools that facilitate the construction of a genuine regional network of rail trails that contributes to sustainable tourism development. 


\section{RESULTS}

\subsection{The view of the trail managers}

Taking the SWOT analysis conducted as a basis, a promising situation for Andalusian rail trails is identified with respect to tourism, in the light of the favourable outlook for the expansion of rural and active tourism in the international context, although not free from difficulties or obstacles to overcome.

However, cycle tourism and other forms of non-motorised tourism based on rail trails are closely conditioned by the length of these routes and the existence of tourism amenities and services, as well as by the presence of other (cultural and natural) resources in the territory that are complementary to the inherent attraction of the trails themselves. Moreover, there is a need for the different territorial actors linked to their maintenance and tourism development to guarantee cooperation. Along with these considerations, the degree of awareness or aptitude of the local population in general and of investors in particular is clearly very important, in order to take advantage of the opportunities for enterprise associated with these routes (Figure 4).

On the basis of this initial perception, developed from the contributions of the different managers interviewed, it is appropriate to design a diagnostic tree for Andalusian rail trails as a preliminary step prior to the subsequent strategy of boosting their tourism development as a network. This diagnostic tree synthesises the reality analysed, and enables specific actions for improvement to be implemented logically and coherently by means of an objectives tree.

Figure 4

TOURISM SWOT FOR ANDALUSIAN RAIL TRAILS

\section{STRENGTHS}

- Institutional consensus on the promotion of ecological transport, the preservation and enjoyment of heritage, proximity to nature, education and interpretation of the visited territory, active tourism, outdoor activities... linked to the Andalusian rail trails.

- Participation of the Administration (at different levels), along with diverse groups of citizens, in promoting the use and exploitation of the trails.

- Increase the capacity of the trails through the recovery of sections and/or facilities that are still out of use.

- Firmness and commitment of the management bodies of the trails.

\section{WEAKNESSES}

- Short length of the routes for their optimum tourism development and exploitation.

User confusion and/or dissolution of the synergies to different levels (local, regional, national) due to the lack of a clear identity of the rail trails.

- Dismantling of the rail trail network in Andalusia.

Lack or shortage of services: accommodation, catering, repair or rental of bicycles, etc. 


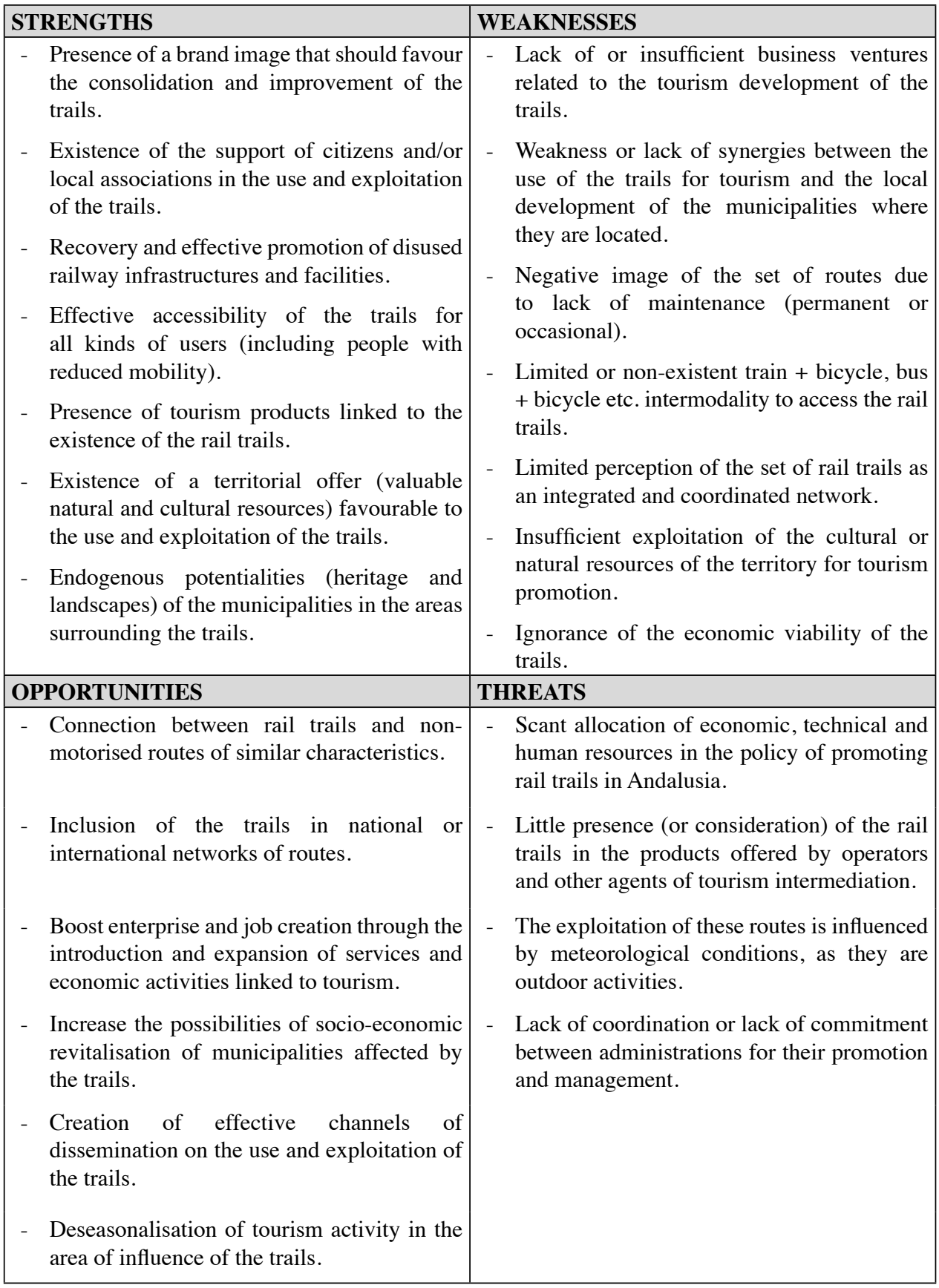




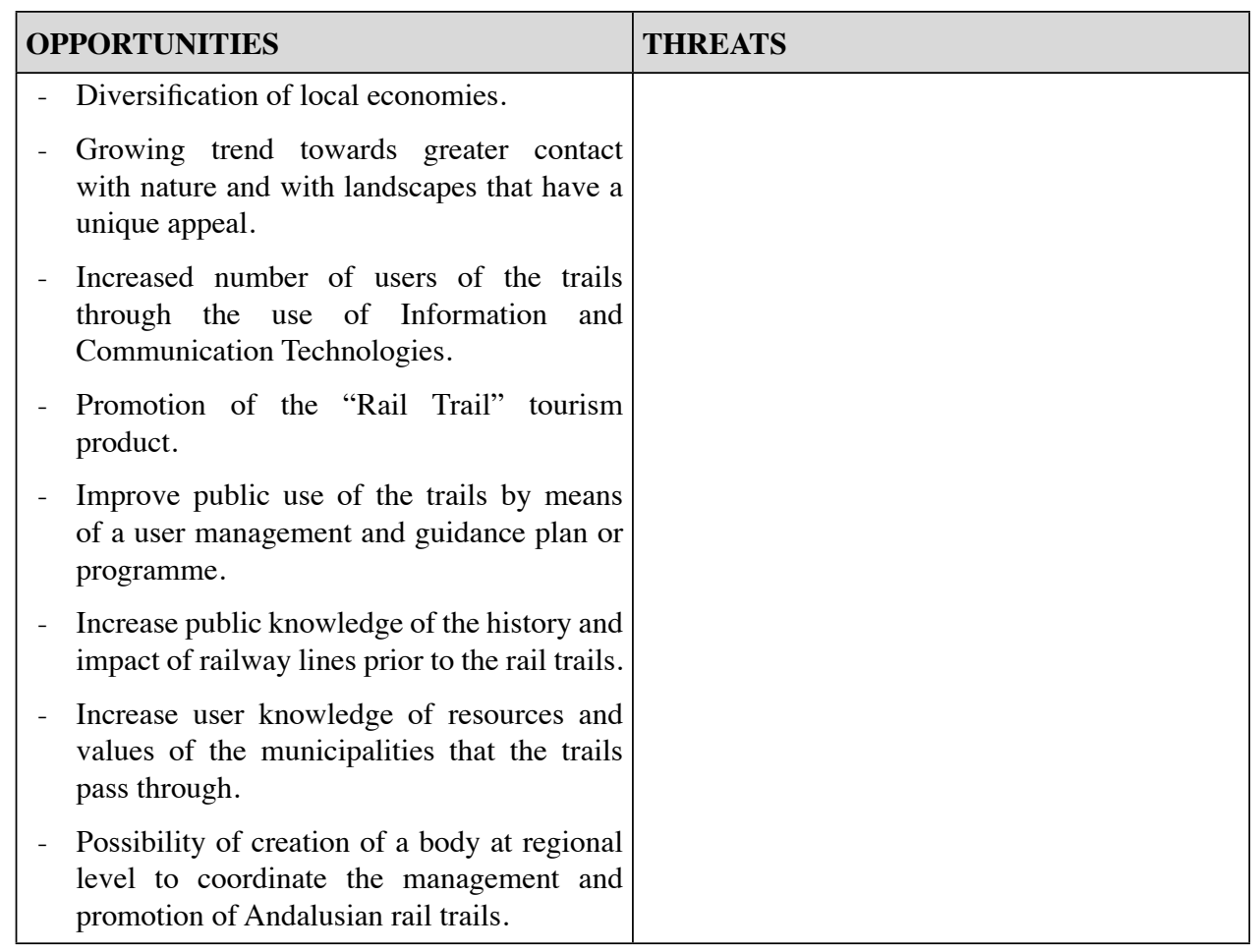

Source: Own preparation.

\subsection{Analysis of the current situation: Diagnostic Tree}

The diagnostic tree created shows three levels in determining the initial situation of the Andalusian rail trails (Figure 5), starting with a preliminary and necessary examination of thematic areas of relevant aspects (level 1). Due to their special importance, 9 of these relevant aspects were identified, which led to three key effects to take into consideration (level 2). In the first key effect, the deficient use and exploitation of the rail trails as a whole, and in the context of sustainable mobility, was observed. In the second key effect, inequality in the integration of the rail trails in fostering socio-economic and territorial development where these are located was observed. Finally, the third key effect evidenced discordant management of this set of non-motorised routes, which affects the scope of the results, the correct allocation of resources (material, financial and human) and those dissemination and promotion efforts aimed at increasing the number of users. These indicated effects enabled the detection of a general conflict (level 3) which ultimately defines the overall situation of the Andalusian rail trails: the lack of a real network of this type of routes, expressed in terms of coherent fostering and promotion, an effective contribution to the sustainable development of the areas where they are located, and equitable and balanced management. 
Nevertheless, despite the deficiencies detected, the diagnostic tree shown evidences a dynamic process, characterised by the constant recovery of disused railway lines and their conversion and use as rail trails. This is all undertaken by a growing number of management bodies, at different rates and with different capacities and commitments to culminate the process, but there is still, however, no clear idea of a network of routes managed in a coordinated fashion.

As well as the above, it is important to take into account the external context of nonmotorised routes existing in and around Andalusia. This increase in rail trails acquires new complementary aspects if the integration of these trails with other types of perfectly compatible thoroughfares is taken into consideration, such as the routes on various scales included in the Andalusian Bicycle Plan (2014-2020), the transnational routes of EuroVelo, or the natural paths and livestock trails present in Andalusia. Consequently, planning a future rail-trail strategy in the Autonomous Community of Andalusia would also require external coherence in its design, seeking to achieve overall compatibility and coordination with other initiatives for establishing and managing a variety of non-motorised routes in addition to rail trails.

Thus, the diagnosis confirms that this tourism product, based on sustainability, shows signs of weakness, both from an internal and an external point of view, in its present process of becoming part of the regional network ofnon-motorised routes. It seems that this is due to a clear dispersion in the management of the network, subject to unconnected development initiatives from the outset, with independent action for each trail, taken from a localist perspective and with mixed results with regard to the development ofthe different routes. Moreover, this issue influences the model of socio-economic development adopted in different rural areas in Andalusia, in its combination with existing territorial resources and in relation to improvements in aspects of thequality of life of local populations and visitors, such as health and leisure. Meanwhile, some successful experiences, such as Vía Verde de La Sierra (Cádiz-Seville) (Luque-Valle, 2012), or, more recently, the combining of three trails into the present Vía Verde del Aceite (Córdoba-Jaén), have served as examples of the capacity of these routes and the potential for the venture and increased local income. They have also been helpful in drawing up some proposals for intervention, set out below, in the form of an objectives tree for a regional strategy for rail trails in Andalusia. 
Figure 5

\section{DIAGNOSTIC TREE OF THE ANDALUSIAN RAIL TRAILS}

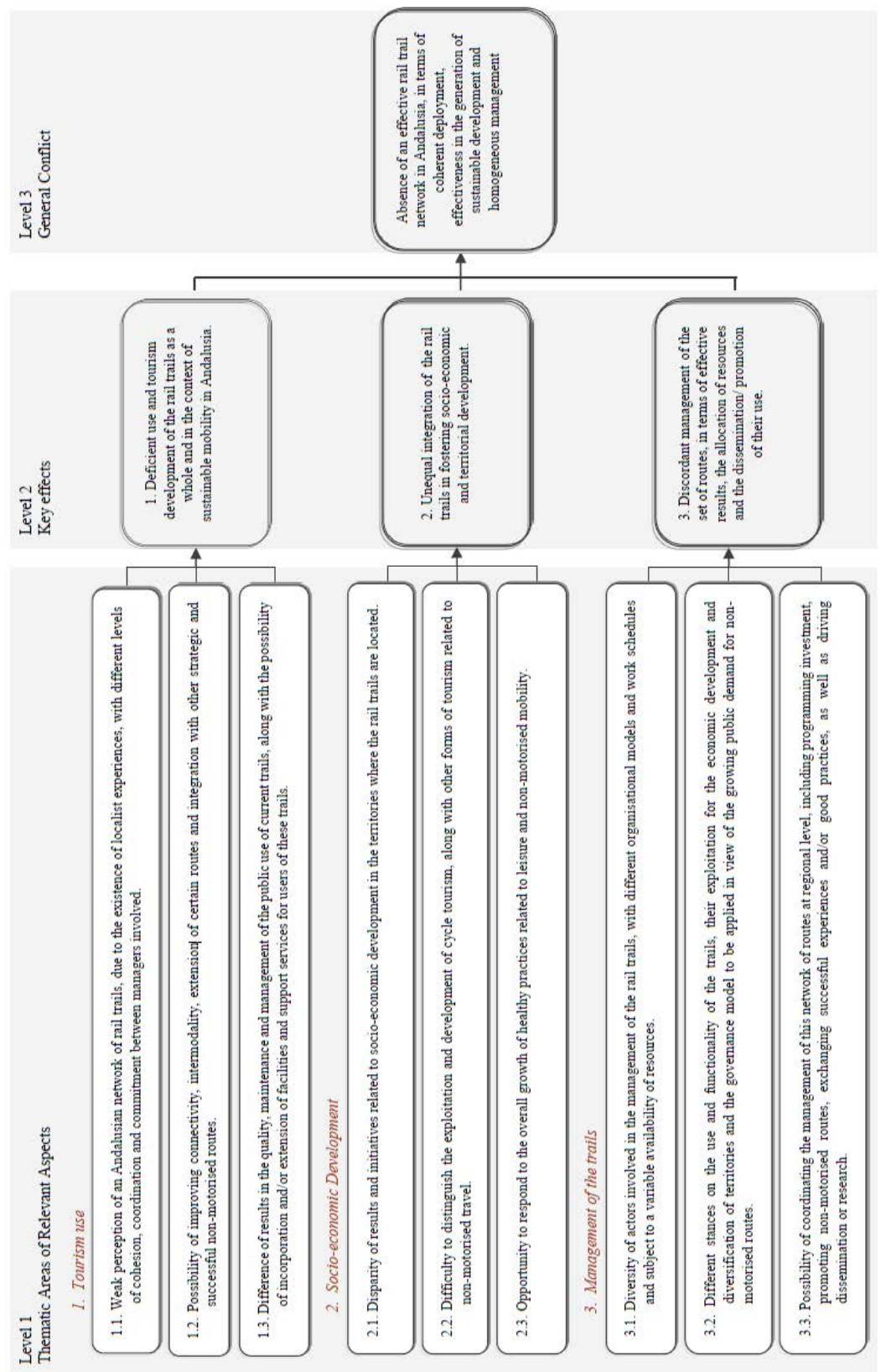

Source: Own preparation. 


\subsection{Proposal for intervention: Objectives Tree}

The objectives tree (Figure 6) shows a triple causal relationship of the goals pursued, on three levels, as a logical response to the general conflict diagnosed and its consequent effects, and assumes the creation of a rail trail network in Andalusia that is coherently deployed, generates sustainable development and is managed homogeneously as general objective (level 3).

The idea is an intervention formula based on three strategic objectives (level 2), in accordance with each goal to be attained (tourism development of the rail trails; promotion of sustainable development in the territories where these are located; and management of the trails perceived as a genuine and effective network). From these emerge nine specific objectives that help to attain the three aforementioned goals (level 1). Thus, in order to achieve the development and exploitation of the non-motorised routes available for use (strategic objective 1), it is necessary to consider them as a whole, as a rail trail network of regional scope connected to a larger set of routes at national and European level, whose maintenance, safety and availability of amenities and/or ancillary services constitute a common feature of the entire trail network. This objective also requires establishing common public usage of the network.

Furthermore, to take full advantage of the opportunities that the network offers for the sustainable socio-economic development of the territories where it is located (strategic objective 2), the promotion of a sustainable tourism model linked to the identification and structuring of opportunities takes on special significance. This model should avail itself of the best practices and successful experiences observed, and act in accordance with the external strategic environment of the network.

Finally, to achieve a management formula based on the coordination and cooperation of all the institutions and actors involved in its creation, conservation and promotion, with a rational allocation of available technical and economic resources (strategic objective 3), it is necessary to strengthen the capacities and boost the means of the different actors who participate. This action should be accompanied by work of dissemination, interpretation and awareness-raising with regard to the network, aimed at creating an authentic and comprehensive information system suited to the strategic planning needs of these trails, serving as an observatory for information, monitoring and assessment.

As can be seen below, the proposal for intervention has the require dinternal coherence, with correspondence between the three levels of the objectives tree and those shown in the diagnosis of the initial situation. This provides a direct response to the different problems and needs detected, by improving the use and tourism development of these trails and their relationship with the immediate surroundings and the territory as a whole, and also via their contribution to the sustainable development of the areas that benefit (with regard to environmental and economic quality and the living standards of their inhabitants). In this way, a more appropriate form of institutional and financial management can be achieved, expressed in terms of the efficiency, rationality, sustainability and coordination of the different actors with responsibility for Andalusia. 
Figure 6

OBJECTIVES TREE FOR THE STRATEGIC PLANNING OF RAIL TRAILS IN ANDALUSIA

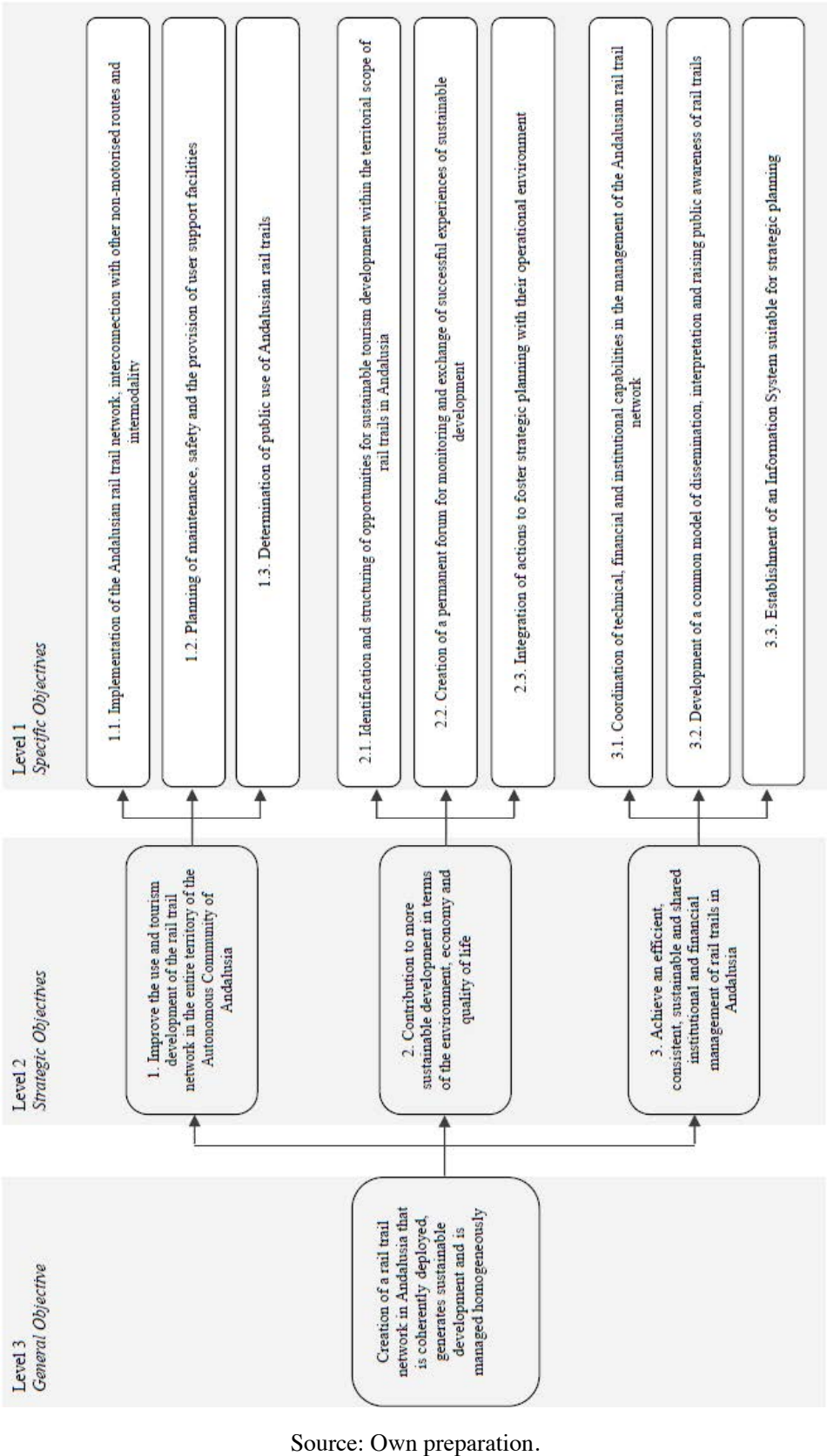

Cuadernos de Turismo, 48, (2021), 209-241 


\section{DISCUSSION AND CONCLUSIONS}

Exploiting rail trails in Andalusia for tourism purposes has great development potential for several reasons. First, the range and diversity of the 27 currently existing routes (which cover almost $580 \mathrm{~km}$ ) should be highlighted, and their possibilities for extension and interconnection with other non-motorised tourist routes (basically livestock trails and rural tracks). Moreover, this offer is boosted by recent improvements in infrastructures and accessibility and by a mild climate during much of the year, which combine to make it highly attractive to the growing demands of cycle tourists, especially from Central Europe. In view of this situation, it certainly makes sense to take advantage of the fact that cycle tourism, and other activities such as hiking, have become important tourism phenomena throughout Europe (Stoffelen, 2018), where trails have been developed on different scales and include routes of varying length, content and setting (MacLeod, 2017).

However, important shortcomings and untapped potential can also be observed with regard to rail trails in Andalusia, and it would be convenient to act upon these as effectively as possible. Management of these rail trails suffers from both a lack of coordination and frequent changes of the competent body entrusted with their promotion. Although we are dealing with a transversal sector, institutional integration in broader regional plans, which are not restricted to one sector, is absolutely crucial (Snowball \& Courtney, 2010). The scenario observed in this research reveals disjointed local-scale planning, the result of initiatives promoted by municipal councils, consortiums, local authority associations known as "mancomunidades" and provincial councils, at different rates and without the necessary coordination of resources. This fact is a weakness as regards the creation of a reliable, long-term response to national and international demand, while at the same time it undermines the socio-economic impact on local communities as a whole.

Hence, and according to the research of Pucher \& Buehler (2006) and Haustein et al. (2020), who have shown that one of the key ingredients for the successful development of routes is to have regional cooperation networks, it is clear that in Andalusia there is a critical need to achieve adequate planning, aimed at constructing a rail trail network at regional level. This would favour and strengthen the development of products, infrastructure and access, and would also facilitate the participation of the local population through the development of micro-businesses and innovation activities. This requires applying a shared and coordinated management model, in line with the strategic planning objectives indicated in this study. The cases of New Zealand and Australia (Faulks et al., 2007) serve as good examples to follow, countries where it has been demonstrated that, although tourists on bicycles may contribute to revitalisation and diversification in rural and regional areas, adequate planning is a key factor in maximising the benefits of economic development that this form of tourism offers.

Nevertheless, there have recently been some cases of a more coherent offer being organised in Andalusia. Examples include the rail trail known as Vía Verde de La Campiña, which is the result of merging two sections that were previously managed separately, and also the new Vía Verde del Aceite, which now combines the old routes of El Aceite, the Subbaetic rail trail and the former Luque-Baena branch line, and comprises a route of 128 $\mathrm{km}$. In this way, the possibility of offering greater options for leisure, sport and tourism 
is increased, with the remodelling of trails of greater territorial scope. If these advances are accompanied by the integration of some existing rail trails into the EuroVelo network, especially in the province of Huelva, as would be the case of El Litoral, it would favour the connection with complementary economic activities and other secondary tourism products (Stoffelen \& Vanneste, 2016), which would help to enhance the strength of the Andalusian rail trail network. In is thus intended to boost the number of tourists and users visiting both the rail trails and their areas of influence.

In short, this paper can help by making proposals for intervention in a tourism sector with great possibilities for the future, for a region with a great tradition and vocation in this sector, but nevertheless requiring actions of diversification and deseasonalisation. Specific recommended actions include administrative and financial support for the recovery of cultural heritage associated with old railway lines. There are still numerous abandoned stations and other railway structures (tunnels, viaducts, stopping places, etc.) that could provide space for new recreational activities, accommodation and catering services. It would therefore be expedient to speed up the transformation of these sites into reception points, centres of interpretation of local heritage, oenogastronomic experiences, bird hides, etc., as well as the provision of essential services for visitors, such as bicycle maintenance facilities, motorhome parking, information points and rest areas. In sum, the recovery of this heritage would contribute to job creationand act as a driver for growth in local economies,as well as enriching the visitor experience and helping to preserve the history of rural communities. All of the above would need to go hand in hand with reinforcing the promotional image of these trails, particularly at a time when cycle tourism is emerging as a growing segment of the tourism industry.

This is all within a context of progressive commitment to sustainable mobility, and the use of non-polluting means of transport and greater intermodality become increasingly important priorities. However, in this case, information from users, local managers and rural populations affected by this tourism product would be of strategic importance if there is a genuine desire to opt for an efficient medium and long term promotion of rail trails in Andalusia. To this end, concerted efforts and specific actions aimed at growth and development should be considered a priority, so that there is a sufficiently coherent management and fostering of sustainable mobility free from significant distortions, offering tourists a real network of non-motorised routes.

Some recommendations for administrations and management bodies can be drawn from the results of this study. On the one hand, setting objectives aimed at designing a strategy for managing Andalusian rail trails as a network is an important step forward in developing these routes in the region. It is necessary to achieve greater conciliation between the context of sustainable mobility and the development of cycle tourism in European rural areas through interconnection with other non-motorised routes and intermodality (García-Bello \& Ventura-Fernández, 2019). On the other hand, the creation of an information system that includes the monitoring and assessment of results and impacts produced, extendable to the entire EU territory, is highly recommendable. This could be achieved by means of a common system of indicators at European level that measure the use and development of the network, its contribution to sustainable regional development and the calibre of the management of the set of routes comprising the network. Despite 
the existence of a consolidated methodology and over a sufficient period of time, basically applied to EuroVelo routes (Mercat, 2018), effective progress in the systematic application of this methodology has not been detected for Andalusia in this study. This fact reduces the possibilities of conducting comparative studies and of applying for support from public funds to promote these leisure activities in the territories where rail trails are located.

Moreover, it should be noted that the international economic-financial crisis has persisted in Andalusia during the course of this research. This has led to a reduction in the public funding available for rail trails, with a consequent slowdown in the planning of the network, both at strategic level and in terms of coordinated management. This is a worrying situation in view of the need for the physical development and coordination of routes, whether localised or linked to the PAB and the international EuroVelo network. In relation to the PAB, it is highly significant that by the first quarter of 2019 , only 142.2 $\mathrm{km}$ have been constructed; or that with only 18 months left of the corresponding period only 261.9 million euros $(58.5 \%)$ of the allotted investment funds of 446.2 million have been used.

With regard to EuroVelo, it should be noted that the development projects for the completion of the two routes that affect Andalusia have been tendered. These are the Atlantic Coast Route (no. 1), which passes through the province of Huelva from north to south and connects with the Portuguese Algarve, and the Mediterranean Route (no. 8), which runs close to the Andalusian Mediterranean coast (provinces of Almería, Granada, Málaga and Cádiz), until it ends in the provincial capital Cádiz. These proposals are currently at the stage of verification by the regional heads of different bodies, which is a further demonstration of the aforementioned lack of coordination or, at the very least, fragmentation of responsibilities. It is necessary to reiterate and emphasise the need for Andalusia to develop coordinated strategic planning to achieve administrative stability, avoid social and spatial dispersion and create a genuine network of rail trails.

\section{ACKNOWLEDGEMENTS}

In previous studies, that have served as a basis for the subsequent development of this research, the authors would like to thank ERDF of the European Union for the financial support received via the project "Creation of a territorial information platform and technological support of rail trails in Andalusia. Citizens' access to the information society" (Creación de una plataforma de información territorial y soporte tecnológico de vías verdes en Andalucía. El acceso de la ciudadanía a la sociedad del conocimiento) (PITVVA; 2013-2015) of the ERDF Operative Programme for Andalusia 2007-2013 ("FEDER Andalucía 2007-2013"). We are also grateful to all the staff at the Public Works Agency and the Department of Development and Housing of the Regional Government of Andalusia for their dedication and professionalism, and those in charge of the management bodies of the Andalusian rail trails for their collaboration and the information provided. Likewise, we are grateful to Dr. Antonio Gavira Narváez for his cartographic contributions in relation to figures 1,2 and 3 of this paper. 
Authorship statement: The authors declare that there is no conflict of interest in relation to the publication of this article. Reyes González-Relaño, Jesús Ventura-Fernández and Gustavo Antonio Contreras-Cabrera have carried out: the literature review, development of the methodology, consultation and treatment of original sources, analysis and discussion of the results and conclusions, and the final revision of the article.

\section{REFERENCES}

ABASCAL, E. and GRANDE, I. (2005): Análisis de encuestas. Madrid, ESIC.

ABILDSO, C.G., ZIZZI, S.J., SELIN, S. and GORDON, P.M. (2012): «Assessing the Cost Effectiveness of Community Rail-Trail in Achieving Physical Activity Gains», Journal of Park and Recreation Administration, vol. 30 (2), pp. 102-113.

ABILDSO, C., BIAS, T. and COFFMAN, J. (2018): "Rur-Ban” Rail-Trail Business Impact: Case Study of the Mon River Trails System in West Virginia, USA». Journal of Transport and Health, vol.9, p. S30. Swansea University. Retrieved from https:// doi.org/10.1016/j.jth.2018.05.089

ALBURQUERQUE, F. and DELGADILLO. J. (2009): Emprendimientos de base ecológica en las áreas de influencia socioeconómica de los Parques Naturales de Andalucía. Sevilla, Instituto de Desarrollo Regional, Fundación Universitaria.

ALDUNATE, E. and CÓRDOBA, J. (2011): Formulación de programas con la metodología de marco lógico. Santiago de Chile, ILPES - CEPAL.

ASTIGARRAGA, E. (2016): «Prospectiva estratégica: orígenes, conceptos clave e introducción a su práctica». Revista Centroamericana de Administración Pública, vol. 71, pp. 13-29. ICAP. Retrieved from http://publicaciones.icap.ac.cr/index.php/ opcion1/164-revista-centroamericana-icap-71

BAKER, T.R. (2001): A method to assess the potential value of railway corridors as recreation trails: A case study of three Nova Scotia rail-trails. Retrieved from http://citeseerx.ist.psu.edu/viewdoc/download?doi=10.1.1.427.5751 andrep=replandtype=pdf

BAKEWELL, O. and GARBUTT, A. (2005): The use and abuse of the logical framework approach. Stockholm, Sida.

BEETON, S. (2006): «Regional Communities and Cycling: The Case of the Murray to the Mountains Rail Trail», Tourism and Hospitality Management, vol. 2, pp. 128-148. University of Rijeka. Retrieved from https://doi.org/10.1504/IJIRD.2010.029859

BELL, C. (2018): "'Great Rides' on New Zealand's new national cycleway: pursuing mobility capital», Landscape Research, vol. 43 (3), pp. 400-409. Landscape Research Group. Retrieved from https://doi.org/10.1080/01426397.2017.1316366

BICHIS-LUPAS. M. and MOISEY, R.N. (2001): «A Benefit Segmentation of Rail-Trail Users: Implications for Marketing by Local Communities», Journal of Park and Recreation Administration vol. 19 (3), pp. 78-92.

CEBRIÁN, F. (2011): «Los ferrocarriles olvidados. Reconversión y reinvención como instrumentos de revitalización recreativa y turística: el Baeza-Utiel a su paso por la provincia de Albacete», Cuadernos de Turismo, $\mathrm{n}^{\circ}$ 27, pp. 205-225. Retrieved from: https://revistas.um.es/turismo/article/view/139841 
CONSEJERÍA DE AGRICULTURA, GANADERÍA, PESCA Y DESARROLLO RURAL (2020): Planes de Zona de Andalucía. Junta de Andalucía. Retrieved from: https:// www.juntadeandalucia.es/organismos/agriculturaganaderiapescaydesarrollosostenible/ areas/desarrollo-rural/marco-andaluz/paginas/aviva-planes-zona.html

COUILLARD, J., GARON, S. and RIZNIC, J. (2009): «The logical framework approachmillennium», Project Management Journal, vol. 40 (4), pp. 31-44. https://doi. org/10.1002/pmj.20117

DAVIES, N. and WESTON, R. (2014): Greenways Product Practitioner Handbook: A guide to evaluating and monitoring greenways. Lancashire. University of Central Lancashire. Retrieved from http://viasverdes.com/prensa/documentos/interes/Greenways Product Practitioner Handbook_final.pdf

DE MARCHI, G., LUCERTINI, G. and TSOUKIÀS, A. (2016): «From evidence-based policy making to policy analytics», Annals of Operations Research, vol. 236 (1), pp. 15-38. Springer Nature. Retrieved fromhttps://hal.archives-ouvertes.fr/hal-01510889/ document

DI RUOCCO, G., SICIGNANO, E., FIORE, P. and D’ANDRIA, E. (2017): «Sustainable reuse of disused railway», Procedia Engineering, vol. 180, pp. 1.643-1.652. Sciencia Direct. Retrieved from https://doi.org/10.1016/j.proeng.2017.04.327.

DICKINSON, J. and LUMSDON, L. (2010): Slow travel and tourism. London, Routledge. DOWNWARD, P., LUMSDON, L. and WESTON, R. (2009): «Visitor expenditure: The case of cycle recreation and tourism», Journal of Sport and Tourism, vol. 14 (1), pp. 25-42. Sports Tourism International Council. Retrieved fromhttps://doi. org/10.1080/14775080902847397

EIZAGUIRRE-IRIBAR, A., IGIÑIZ, L.E. and HERNÁNDEZ-MINGUILLÓN, R.J. (2016): «A multilevel approach of non-motorised accessibility in disused railway systems: The case-study of the Vasco-Navarro railway», Journal of Transport Geography, vol. 57, pp. 35-43. Sciencia Direct. Retrieved fromhttps://doi.org/10.1016/j. jtrangeo.2016.09.009

EIZAGUIRRE-IRIBAR, A. and GRIJALBA, O. (2020): «A methodological proposal for the analysis of disused railway lines as territorial structuring elements: The case study of the Vasco-Navarro railway». Land Use Policy, vol. 91, p. 104.406 https://doi. org/10.1016/j.landusepol.2019.104406

EVENSON, K.R., HERRING, A.H. and HUSTON, S.L. (2005): «Evaluating change in physical activity with the building of a multi-use trail», American journal of preventive medicine, vol. 28 (2), pp. 177-185. ACPM-APTR. Retrieved fromhttps://doi. org/10.1016/j.amepre.2004.10.020

EUROPEAN CYCLIST'S FEDERATION (ECF) (2020): EuroVelo. Retrieved from https://en .eurovelo.com/

EUROPEAN GREENWAYS ASSOCIATION (2000): Declaración para una "Red Verde Europea”. Declaración de Lille. Retrieved from http://www.aevv-egwa.org/es/declaracion-para-una-red-verde-europea/\#

FERRETTI, V. and DEGIOANNI, A. (2017): «How to support the design and evaluation of redevelopment projects for disused railways? A methodological proposal and key 
lessons learned», Transportation Research Part D: Transport and Environment, vol. 52, pp. 29-48. Elsevier. Retrieved fromhttps://doi.org/10.1016/j.trd.2017.02.008

FAULKS, P., RITCHIE, B.W. and FLUKER, M. (2007): Cycle tourism in Australia: an investigation into its size and scope. Gold Coast, Sustainable Tourism CRC.

FFE-FUNDACIÓN DE LOS FERROCARRILES ESPAÑOLES (2011): Desarrollo sostenible y empleo en las vías verdes. España: Dirección de Actividades Ambientales y Vías Verdes. Madrid, Fundación de los Ferrocarriles Españoles. Retrieved from http:// viasverdes.com/prensa/documentos/interes/libro_emplea_verde.pdf

FFE-FUNDACIÓN DE LOS FERROCARRILES ESPAÑOLES and UNIVERSIDAD DE SEVILLA (2014): El impacto económico del cicloturismo en Europa. Síntesis de los principales estudios realizados. Agencia de Obra Pública de la Junta de Andalucía. Consejería de Fomento y Vivienda. Junta de Andalucía. Retrieved from http://www. viasverdes.com/prensa/documentos/interes/Informe_Cicloturismo_2014.pdf

GARCÍA, A., CALDERÓN, F., PÉREZ, S. and PODADERA, P. (2004): Planificación estratégica sostenible de redes territoriales. Teoría y práctica. Málaga, Ed. Universidad de Málaga/Debates.

GARCÍA-BELLO, I.A. and VENTURA-FERNÁNDEZ, J. (2019): «Aproximación Metodológica a los Itinerarios no Motorizados de Mayor Potencialidad para la Intermodalidad "Tren+Bici” en Andalucía», Revista de Estudios Andaluces, no 38, pp. 185-207. Retrieved from: https://institucional.us.es/revistas/andaluces/38/10_GarciaBello_Ventura-Fern\%C3\%A1ndez.pdf

GASPER, D. (2000): «Evaluating the 'logical framework approach' towards learningoriented development evaluation», Public administration and development, vol.20 (1), pp. 17-28. Wiley Online Library. Retrieved fromhttps://doi.org/10.1002/1099-162X

GIBSON, H. and CHANG, S. (2012): «Cycling in mid and later life: Involvement and benefits sought from a bicycle tour», Journal of Leisure Research, vol. 44 (1), pp. 23-51. NRPA. Retrieved from https://doi.org/10.1080/00222216.2012.11950253

GODET, M. and DURANCE, P. (2009): La prospectiva estratégica para las empresas y los territorios. Retrieved from https://administracion.uexternado.edu.co/matdi/clap/ La\%20prospectiva\%20estrategica.pdf

GREEN, J. (2009): "“Walk this way": public health and the social organization of walking», Social Theory and Health, vol. 7 (1), pp. 20-38. Palgrave Macmillan. Retrieved from https://doi.org/10.1057/sth.2008.19

GUERRIERI, M. and TICALI, D. (2012): «Sustainable mobility in park areas: the potential offered by guided transport systems», Integrating Sustainability Practices in the Construction Industry, 2011, pp. 661-668. American Society of Civil Engineers. Retrieved from https://ascelibrary.org/doi/pdf/10.1061/41204\%28426\%2981

HAUSTEIN, S., KOGLIN, T., NIELSEN, T.A.S . and SVENSSON, A. (2020): «A comparison of cycling cultures in Stockholm and Copenhagen», International Journal of Sustainable Transportation, vol. 14 (4), pp. 280-293. Taylor and Francis Online. Retrieved from https://doi.org/10.1080/15568318.2018.1547463

KACZYNSKI, A.T. and HENDERSON, K.A. (2007): «Environmental correlates of physical activity: a review of evidence about parks and recreation», Leisure Sciences, vol. 29 (4), pp. 315-354. Taylor and Francis Online. Retrieved from https://doi. org/10.1080/01490400701394865 
LAMONT, M. (2009): "Reinventing the Wheel: «A Definitional Discussion of Bicycle Tourism», Journal of Sport and Tourism, vol. 14 (1), pp. 5-23. Taylor and Francis Online. Retrieved from https://doi.org/10.1080/14775080902847363

LAS CASAS, G. and SCORZA, F. (2016). «Sustainable planning: a methodological toolkit», in International Conference on Computational Science and Its Applications. Springer, Cham, pp. 627-635.

LITMAN, T. (2010): Quantifying the benefits of non motorized transportation for achieving mobility management objectives. Victoria Transport Policy Institute, 28. Retrieved from http://artshenkman.com/cs/groups/content/@webottawa/documents/pdf/mdaw/ mdy3/ edisp/con056214.pdf

LUMSDON, L. (2000): «Transport and tourism: cycle tourism-a model for sustainable development? », Journal of Sustainable Tourism, vol. 8 (5), pp. 361-377. Taylor and Francis Online. Retrieved fromhttps://doi.org/10.1080/09669580008667373

LUMSDON, L., DOWNWARD, P. and COPE, A. (2004): «Monitoring of cycle tourism on long distance trails: the North Sea Cycle Route», Journal of Transport Geography, vol. 12 (1), pp. 13-22. Elsevier. Retrieved from https://doi.org/10.1016/j.jtrangeo.2003.10.007

LUMSDON, L. M., WESTON, R., DAVIES, N.J., MCGRATH, P., PEETERS, P., EIJGELAAR, E., and PIKET, P. (2009): The European cycle route network, Eurovelo. Retrieved from http://clok.uclan.ac.uk/23243/1/EuroVelo\%20final\%20report.pdf

LUQUE-VALLE, P. (2012): Análisis del modelo de uso-visita de los deportistas-turistas de las vías verdes andaluzas. PhD Tesis, Granada, Universidad de Granada. Retrieved from http://hdl.handle.net/10481/20995

LUQUE-VALLE, P. and REBOLLO RICO, S. (2012): «Las vías verdes son las instalaciones deportivas del futuro: espacios para realizar deporte en plena naturaleza», EmásF: Revista Digital de Educación Física, n 19, pp. 180-194. JCMD. Retrieved from https://emasf2.webcindario.com/NUMERO_19_EMASF.pdf

MANTON, R., HYNES, S. and CLIFFORD, E. (2016). «Greenways as a tourism resource: a study of user spending and value», Tourism Planning and Development, vol. 13 (4), pp. 427-448. Taylor and Francis Online. Retrieved from https://doi.org/10.1080/2156 8316.2015.1136835

MARTÍN, A. (2018): Las Verdes y Red Natura 2000: Divulgación de Espacios Naturales Protegidos y Geoparques a través de la Red Estatal de Vías Verdes. Retrieved from http://viasverdes.com/publicaciones/PDF/2INFORME\%20VVyREDNatura2000.pdf

MCKERCHER, B. (2001): «Attitudes to a non-viable community-owned heritage tourist attraction», Journal of Sustainable Tourism, vol. 9 (1), pp. 29-43. Taylor and Francis Online. Retrieved fromhttps://doi.org/10.1080/09669580108667387

MACLEOD, N. (2017). «The role of trails in the creation of tourist space», Journal of Heritage Tourism, vol. 12 (5), pp. 423-430. Taylor and Francis Online. Retrieved from https://doi.org/10.1080/1743873X.2016.1242590

MERCAT, N. (2018): «El caso de Francia», in JIMÉNEZ, M. and BRUNO, P. (Presidency), Conferencia 25 Años de Vías Verdes, Sevilla, España. Fundación de Ferrocarriles Españoles-Asociación Andaluza de Vías Verdes, Retrieved from http://www. viasverdes.com/pdf/Ponencias25VV/S202_Mercat_Inddigo.pdf 
MINISTERIO DE AGRICULTURA, PESCA Y ALIMENTACIÓN (2020): Programa de Desarrollo Rural Sostenible (PDRS). Retrieved from: https://www.mapa.gob.es/es/ desarrollo-rural/planes-y-estrategias/ley-para-el-desarrollo-sostenible-del-medio-rural/ prog-desarrollo-rural-sostenible/

MOORE, R.L. and SHAFER, C.S. (2001): «Introduction to special issue trails and greenways: Opportunities for planners, managers, and scholars»; Journal of park and recreation administration, vol. 1 (3), pp. 1-16.

MORAL, M. (2016): «La puesta en valor de un recurso turístico cultural sostenible en el medio rural: El caso de las Vías Verdes en España», Revista Interamericana de Ambiente y Turismo, vol. 12 (2), pp. 161-175.

MUNDET, L. and COENDERS, G. (2010): «Greenways: a sustainable leisure experience concept for both communities and tourists», Journal of Sustainable Tourism, vol. 18 (5), pp. 657-674. Taylor and Francis Online. Retrieved from https://doi. org/10.1080/09669581003668524

OSWALD BEILER, M., BURKHART, K. and NICHOLSON, M. (2015): «Evaluating the impact of rail-trails: A methodology for assessing travel demand and economic impacts», International Journal of Sustainable Transportation, vol. 9 (7), pp. 509-519. Taylor and Francis Online. Retrieved from https://doi.org/10.1080/1 5568318.2013.825035

PARKIN, J., RYLEY, T.J. and JONES, T.J. (2007): Barriers to cycling: an exploration of quantitative analyses. Bolton, University of Bolton. Retrieved from https://www. taylorfrancis.com/books/e/9781315575735/chapters/10.4324/9781315575735-9

PLATAFORMA REPRESENTATIVA ESTATAL DE PERSONAS CON DISCAPACIDAD FÍSICA and FUNDACIÓN DE LOS FERROCARRILES ESPAÑOLES (2017): Practical Guide to Opening Up the territory on Accessible Greenways. Retrieved from http://viasverdes.com/publicaciones/PDF/GuiaPractica_TurismoAccesible_ViasVerdes_GW4ALL.pdf

PUCHER, J. and BUEHLER, R. (2006): «Sustainable Transport in Canadian Cities: Cycling Trends and Policies», Berkeley Planning Journal, vol. 19 (1), pp. 104-108. University of California, Berkeley. Retrieved from https://doi.org/10.5070/BP319111491

QUATTRONE, M., TOMASELLI, G., D'EMILIO, A. and RUSSO, P. (2018): «Analysis and evaluation of abandoned railways aimed at greenway conversion: a methodological application in the Sicilian landscape using Multi-criteria analysis and GIS», Journal of Agricultural Engineering, vol. 49 (3), pp. 151-163, Italian Society of Agricultural Engineering. University of Bologna. Retrieved from https://doi.org/10.4081/ jae.2018.744

RAMÍREZ, J.L. (2009): Procedimiento para la elaboración de un análisis FODA como una herramienta de planeación estratégica en las empresas. Guadalajara. Universidad de Guadalajara. Retrieved from https:/www.uv.mx/iiesca/files/2012/12/herramienta2009-2.pdf

REIS, A. C. and JELLUM, C. (2012): «Rail Trail Development: A Conceptual Model for Sustainable Tourism», Tourism Planning and Development, vol. 9 (2), pp. 133-147. Taylor and Francis Online. Retrieved fromhttps://doi.org/10.1080/21568316.2011.63 0748 
REIS, A. C., LOVELOCK, B. and JELLUM, C. (2014): «Linking tourism products to enhance cycle tourism: the case of the Taieri Gorge Railway and the Otago Central Rail Trail, New Zealand», Tourism Review International, vol. 18 (1), pp. 57-69. Cognizant Communication Corp. Retrieved from http://dx.doi.org/10.3727/1544272 $14 X 13990420684527$

RINCÓN-MILLÁN, J. (2013): La antigua línea de ferrocarril Jerez-Almargen: su reconversión en camino natural. Tesis doctoral. Sevilla, Universidad de Sevilla. Retrieved from http://hdl.handle.net/11441/47570

RITCHIE, B.W., TKACZYNSKI, A. and FAULKS, P. (2010): «Understanding the motivation and travel behavior of cycle tourists using involvement profiles», Journal of Travel and Tourism Marketing, vol. 27 (4), pp. 409-425. Taylor and Francis Online. Retrieved fromhttps://doi.org/10.1080/10548408.2010.481582

RODRÍGUEZ MORENO, J. (2016): La motivación del turismo deportivo en espacios naturales ( $\mathrm{PhD}$ Thesis). Universitas Miguel Hernández, Elche, España. Retrieved from http://dspace.umh.es/bitstream/11000/2698/1/TD\%20Rodr\%C3\%ADguez\%20 Moreno,\%20Jes\%C3\%BAs.pdf

RODUNER, D., SCHLÄPPI, W. and EGLI, W. (2008): «Logical Framework Approach and Outcome Mapping, A Constructive Attempt of Synthesis». Rural Development News, 2, 1-24. AGRIDEA-NADEL ETHZ. Retrieved from https://www.zewo.ch/wpcontent/uploads/2019/11/A-Constructive-Attempt-of-Synthesis-5.pdf

SCOTT, D., GÖSSLING, S.G. and PEETERS, P.M. (2010): «Can tourism deliver its 'aspirational' greenhouse gas emission reduction targets?». Journal of Sustainable Tourism, 18 (3), pp. 393-408. Taylor and Francis Online. Retrieved fromhttps://doi. org/10.1080/09669581003653542

SENES, G., ROVELLI, R., BERTONI, D., ARATA, L., FUMAGALLI, N. and TOCCOLINI, A. (2017): «Factors influencing greenways use: Definition of a method for estimation in the Italian context». Journal of transport geography, 65, 175-187. Elsevier. Retrieved fromhttps://doi.org/10.1016/j.jtrangeo.2017.10.014

SERRA, M.S.I. (2016): «El cicloturismo y las vías verdes como ejemplo de turismo sostenible». Revista CIDOB d'Afers Internacionals, vol. 113, pp. 187-209. CIDOB. Retrieved from https://doi.org/10.24241/rcai.2016.113.2.187

SNOWBALL, J.D. and COURTNEY, S. (2010): «Cultural heritage routes in South Africa: Effective tools for heritage conservation and local economic development?». Development Southern Africa, vol. 27 (4), pp. 563-576. Taylor and Francis Online. Retrieved from https://doi.org/10.1080/0376835X.2010.508589

SPENCER, D.M. (2013): «Understanding local versus tourist visitors to recreation areas». Managing Leisure, vol. 18 (1), pp. 1-15. Taylor and Francis Online. Retrieved fromhttps://doi.org/10.1080/13606719.2012.711603

STOFFELEN, A. (2018): «Tourism trails as tools for cross-border integration: A best practice case study of the Vennbahn cycling route». Annals of Tourism Research, vol. 73, pp. 91-102. Elsevier. Retrieved from https://doi.org/10.1016/j.annals.2018.09.008

STOFFELEN, A. and VANNESTE, D. (2016): «Institutional (Dir.) integration and regional development implications of whisky tourism in Speyside, Scotland». Scandinavian 
Journal of Hospitality and Tourism, vol. 16 (1), pp. 42-60. Taylor and Francis Online. Retrieved from https://doi.org/10.1080/15022250.2015.1062416

SUSTRANS (1999): Cycle Tourism. Bristol, Information Pack TT21.

TAYLOR, P. (2015): «What factors make rail trails successful as tourism attractions?

Developing a conceptual framework from relevant literature». Journal of Outdoor Recreation and Tourism, vol. 12, pp. 89-98. Elsevier. Retrieved from https://doi. org/10.1016/j.jort.2015.11.005

TIMOTHY, D.J. and BOYD. S.W. (2014): Tourism and trails: Cultural, ecological and management issues (Vol. 64). Bristol, Channel View Publications

VALLS, J.F. and NEVES, J. (2014): «La planificación estratégica de los destinos turísticos». In: FLORES, D. (Coord.), Manual de gestión de destinos turísticos. Valencia, Tirant lo Blanch.

VAN BLARCOM, B. and JANMAAT, J. (2013): «Comparing the costs and health benefits of a proposed rail trail». Journal of Policy Research in Tourism, Leisure and Events, vol. 5 (2), pp. 187-206. Taylor and Francis Online. Retrieved from https://doi.org/10. 1080/19407963.2013.789729

VENTURA-FERNÁNDEZ, J. and GAVIRA-NARVÁEZ, A. (2016): Las vías verdes como dinamizadoras del desarrollo territorial sostenible en Andalucía. Retrieved from http://abcblogs.abc .es/riqueza-regiones/2016/02/22/las-vias-verdes-como-dinamizadoras-del-desarrollo-territorial-sostenible-en-andalucia/

VENTURA FERNÁNDEZ, J., GONZÁLEZ-RELAÑO, R. and GAVIRA-NARVÁEZ, A. (2017): «Accessibility of rail trails in Huelva, Andalusia (Spain)». Journal of Maps, vol. 13 (1), pp. 62-66. Retrieved from https://doi.org/10.1080/17445647.2017.1323033

VÍAS VERDES DE ANDALUCÍA (2020): Itinerarios. Retrieved from https://www.viasverdes.com/vvandalucia/itinerarios/principal.asp

WILLARD, P. and BEETON, S. (2012): «Low Impact Experiences: Developing Successful Rail Trail Tourism». Tourism Planning and Development, vol. 9 (1), pp. 5-13. Taylor and Francis Online. Retrieved from https://doi.org/10.1080/21568316.2012.65 3476 
Annex 1

CHARACTERISATION OF RAIL TRAILS IN ANDALUSIA

\begin{tabular}{|c|c|c|c|}
\hline NAME* & PROVINCE(S) & LENGTH & TOWNS and CITIES EN ROUTE \\
\hline $\begin{array}{l}\text { V.V.de } \\
\text { Lucainena de las } \\
\text { Torres } \\
\end{array}$ & Almería & $5 \mathrm{~km}$ & Lucainena de las Torres \\
\hline $\begin{array}{l}\text { V.V. FC. Guadix- } \\
\text { Almendricos } \\
\text { (tramo Valle del } \\
\text { Almanzora) }\end{array}$ & Almería & $38.5 \mathrm{~km}$ & $\begin{array}{l}\text { Between Fines and the vicinity of the } \\
\text { station at Hijate (Alcóntar) }\end{array}$ \\
\hline $\begin{array}{l}\text { V.V. del FC. } \\
\text { Guadix- } \\
\text { Almendricos } \\
\text { (Almendricos- } \\
\text { Huércal-Overa) }\end{array}$ & $\begin{array}{l}\text { Almería and } \\
\text { Murcia }\end{array}$ & $23.57 \mathrm{~km}$ & Lorca and Huércal-Overa \\
\hline V.V. de la Sierra & Cádiz and Seville & $36 \mathrm{~km}$ & $\begin{array}{l}\text { Puerto Serrano and Olvera in Cádiz; } \\
\text { and Coripe, Montellano and El Coronil } \\
\text { in Seville }\end{array}$ \\
\hline V.V.Entre Ríos & Cádiz & $16.2 \mathrm{~km}$ & Rota and Chipiona \\
\hline $\begin{array}{l}\text { V.V. Puerto Real } \\
\text { - San Fernando }\end{array}$ & Cádiz & $8.25 \mathrm{~km}$ & Puerto Real and San Fernando \\
\hline V.V. Matagorda & Cádiz & $3.6 \mathrm{~km}$ & Puerto Real \\
\hline $\begin{array}{l}\text { V.V.de la } \\
\text { Campiña }\end{array}$ & $\begin{array}{l}\text { Córdoba and } \\
\text { Seville }\end{array}$ & $91.38 \mathrm{~km}$ & $\begin{array}{l}\text { Córdoba, Guadalcazar, La Rambla } \\
\text { and La Carlota in Córdoba; and Écija, } \\
\text { Fuente Palmera, La Luisiana, Fuentes } \\
\text { de Andalucía and Marchena in Seville }\end{array}$ \\
\hline V.V. del Aceite & Córdoba and Jaén & $128 \mathrm{~km}$ & $\begin{array}{l}\text { Luque, Baena, Zuheros, Doña } \\
\text { Mencía, Cabra, Lucena, Moriles, } \\
\text { Aguilar de la Frontera and Puente } \\
\text { Genil in Córdoba; and Jaén, Torre del } \\
\text { Campo, Torredonjimeno, Martos and } \\
\text { Alcaudete in Jaén }\end{array}$ \\
\hline $\begin{array}{l}\text { V.V. de la } \\
\text { Maquinilla }\end{array}$ & Córdoba & $8 \mathrm{~km}$ & Belmez and Peñarroya-Pueblonuevo \\
\hline $\begin{array}{l}\text { V.V. Peñarroya- } \\
\text { Pueblonuevo }\end{array}$ & Córdoba & $3.2 \mathrm{~km}$ & Peñarroya-Pueblonuevo \\
\hline $\begin{array}{l}\text { V.V. de la } \\
\text { Minería }\end{array}$ & Córdoba & $14.6 \mathrm{~km}$ & $\begin{array}{l}\text { Villanueva del Duque and Hinojosa } \\
\text { del Duque }\end{array}$ \\
\hline $\begin{array}{l}\text { V.V. Fuente } \\
\text { Obejuna }\end{array}$ & Córdoba & $4.5 \mathrm{~km}$ & Fuente Obejuna \\
\hline V.V.del Cerco & Córdoba & $2 \mathrm{~km}$ & Peñarroya-Pueblonuevo \\
\hline $\begin{array}{l}\text { V.V.de Sierra } \\
\text { Nevada }\end{array}$ & Granada & $1.65 \mathrm{~km}$ & Güejar Sierra \\
\hline
\end{tabular}




\begin{tabular}{|l|l|l|l|}
\hline $\begin{array}{l}\text { V.V. FC. Guadix- } \\
\text { Almendricos } \\
\text { tramo Sierra de } \\
\text { Baza) }\end{array}$ & Granada & $16 \mathrm{~km}$ & Baza and Caniles \\
\hline $\begin{array}{l}\text { V.V. del } \\
\text { Guadiana }\end{array}$ & Huelva & $16.7 \mathrm{~km}$ & El Almendro and El Granado \\
\hline V.V. del Litoral & Huelva & $48.7 \mathrm{~km}$ & $\begin{array}{l}\text { Ayamonte, Lepe, Isla Cristina, Cartaya } \\
\text { and Gibraleón }\end{array}$ \\
\hline $\begin{array}{l}\text { V.V. de Molinos } \\
\text { del Agua }\end{array}$ & Huelva & $33.2 \mathrm{~km}$ & $\begin{array}{l}\text { San Juan del Puerto, Trigueros, Beas } \\
\text { and Valverde del Camino }\end{array}$ \\
\hline $\begin{array}{l}\text { V.V. del } \\
\text { Guadalimar }\end{array}$ & Jaén & $15.3 \mathrm{~km}$ & $\begin{array}{l}\text { Linares, Ibros, Lupión, } \\
\text { Torreblascopedro and Begíjar }\end{array}$ \\
\hline V.V.de Linares & Jaén & $6.6 \mathrm{~km}$ & Linares \\
\hline V.V. de Vadollano & Jaén & $6.7 \mathrm{~km}$ & Linares \\
\hline V.V. de Segura & Jaén & $27 \mathrm{~km}$ & $\begin{array}{l}\text { Arroyo del Ojanco, Segura de la } \\
\text { Sierra, Puente de Génave, La Puerta de } \\
\text { Segura, Génave and Villarrodrigo }\end{array}$ \\
\hline V.V.de Itálica & Seville & $2.75 \mathrm{~km}$ & Seville and Camas \\
\hline $\begin{array}{l}\text { V.V. de la Sierra } \\
\text { Norte de Sevilla }\end{array}$ & Seville & $18.7 \mathrm{~km}$ & $\begin{array}{l}\text { Cazalla de la Sierra, Alanís, San } \\
\text { Nicolás del Puerto and Constantina }\end{array}$ \\
\hline $\begin{array}{l}\text { V.V. de El } \\
\text { Ronquillo }\end{array}$ & Seville & $9.2 \mathrm{~km}$ & El Ronquillo \\
\hline $\begin{array}{l}\text { V.V. de Las } \\
\text { Lagunas }\end{array}$ & Seville & $11 \mathrm{~km}$ & $\begin{array}{l}\text { La Roda de Andalucía, Estepa and } \\
\text { Pedrera. }\end{array}$ \\
\hline
\end{tabular}

Source: own preparation based on Vías Verdes de Andalucía (2020).

*Note: V.V. = Vía Verde (Rail Trail) 


\section{Annex 2}

\section{LEVEL OF RECURRENCE OF MANAGEMENT BODIES' SWOT REPLIES}

\begin{tabular}{|c|c|}
\hline Strengths & Recurrence* \\
\hline $\begin{array}{l}\text { Institutional consensus on the promotion of ecological transport, the preservation } \\
\text { and enjoyment of heritage, proximity to nature, education and interpretation of } \\
\text { the visited territory, active tourism, outdoor activities... linked to the Andalusian } \\
\text { rail trails. }\end{array}$ & M \\
\hline $\begin{array}{l}\text { Promotion of accessibility as a universal resource for the entire trail user } \\
\text { population (regardless of age, gender or physical condition). }\end{array}$ & $\mathrm{L}$ \\
\hline $\begin{array}{l}\text { Participation of the Administration (at different levels), along with diverse groups } \\
\text { of citizens, in promoting the use and exploitation of the trails. }\end{array}$ & M \\
\hline $\begin{array}{l}\text { Development of local tourism activity associated with the trails as the user's main } \\
\text { reason for making the trip. }\end{array}$ & $\mathrm{L}$ \\
\hline $\begin{array}{l}\text { Contribution to the maintenance and deseasonalisation of local tourism activity } \\
\text { associated with the trails as a complementary tourist attraction to other types of } \\
\text { tourism existing in the vicinity. }\end{array}$ & $\mathrm{L}$ \\
\hline Firmness and commitment of the management bodies of the trails. & M \\
\hline $\begin{array}{l}\text { Presence of a brand image that should favour the consolidation and improvement } \\
\text { of the trails. }\end{array}$ & M \\
\hline $\begin{array}{l}\text { Existence of the support of citizens and/or local associations in the use and } \\
\text { exploitation of the trails. }\end{array}$ & M \\
\hline $\begin{array}{l}\text { Existence of a strategy driving the dissemination of the trails to increase their use } \\
\text { and development (advertising campaigns, etc). }\end{array}$ & $\mathrm{L}$ \\
\hline Recovery and effective promotion of disused railway infrastructures and facilities. & M \\
\hline $\begin{array}{l}\text { Existence of sufficient converted/rehabilitated railway resources (stations, } \\
\text { warehouses, enclosures and open spaces, etc.) to maintain or improve the tourist } \\
\text { and recreational attraction of the trails. }\end{array}$ & $\mathrm{L}$ \\
\hline $\begin{array}{l}\text { Availability or sufficiency of rest areas, accommodation, food, toilets, rental or } \\
\text { repair of bicycles and other services or facilities linked to the trail. }\end{array}$ & $\mathrm{L}$ \\
\hline $\begin{array}{l}\text { Effective accessibility of the trails for all kinds of users (including people with } \\
\text { reduced mobility). }\end{array}$ & M \\
\hline Presence of tourism products linked to the existence of the rail trails. & $\mathrm{M}$ \\
\hline $\begin{array}{l}\text { Existence of a territorial offer (valuable natural and cultural resources) favourable } \\
\text { to the use and exploitation of the trails. }\end{array}$ & M \\
\hline $\begin{array}{l}\text { Endogenous potentialities (heritage and landscapes) of the municipalities in the } \\
\text { areas surrounding the trails. }\end{array}$ & M \\
\hline Weaknesses & Recurrence * \\
\hline Short length of the routes for their optimum tourism development and exploitation. & $\mathrm{M}$ \\
\hline Lack of connection with other nearby cycle tourism routes & $\mathrm{L}$ \\
\hline $\begin{array}{l}\text { Lack or shortage of services: accommodation, catering, repair or rental of } \\
\text { bicycles, etc. }\end{array}$ & M \\
\hline \begin{tabular}{|l|} 
Insufficient recognition of the Rail Trail brand by the population. \\
\end{tabular} & $\mathrm{L}$ \\
\hline
\end{tabular}




\begin{tabular}{|c|c|}
\hline $\begin{array}{l}\text { Difficulty to offer diverse use options (freely or via commercial products designed } \\
\text { to promote tourism, educational characteristics, etc.). }\end{array}$ & $\mathrm{L}$ \\
\hline $\begin{array}{l}\text { Lack of actions to involve the local population in the use and/or harnessing the } \\
\text { socio-economic benefits of the trails. }\end{array}$ & $\mathrm{L}$ \\
\hline $\begin{array}{l}\text { Lack of or insufficient business ventures related to the tourism development of } \\
\text { the trails. }\end{array}$ & $\mathrm{H}$ \\
\hline $\begin{array}{l}\text { Weakness or lack of synergies between the use of the trails for tourism and the } \\
\text { local development of the municipalities where they are located. }\end{array}$ & M \\
\hline $\begin{array}{l}\text { Negative image of the set of routes due to lack of maintenance (permanent or } \\
\text { occasional). }\end{array}$ & M \\
\hline $\begin{array}{l}\text { Lack of a specific legal framework for rail trails regulating their use and } \\
\text { development. }\end{array}$ & $\mathrm{L}$ \\
\hline $\begin{array}{l}\text { Scarcity or lack of promotion and dissemination measures (advertising campaigns, } \\
\text { etc.). }\end{array}$ & $\mathrm{L}$ \\
\hline $\begin{array}{l}\text { Limited or non-existent train }+ \text { bicycle, bus }+ \text { bicycle etc. intermodality to access } \\
\text { the rail trails. }\end{array}$ & M \\
\hline Overload of visitors to, or users of, the trails. & $\mathrm{L}$ \\
\hline $\begin{array}{l}\text { Limited perception of the set of rail trails as an integrated and coordinated } \\
\text { network. }\end{array}$ & M \\
\hline $\begin{array}{l}\text { Insufficient exploitation of the cultural or natural resources of the territory for } \\
\text { tourism promotion. }\end{array}$ & M \\
\hline Ignorance of the economic viability of the trails. & $\mathrm{M}$ \\
\hline Opportunities & Recurrence * \\
\hline $\begin{array}{l}\text { Increase the capacity of the trails through the recovery of sections and/or facilities } \\
\text { that are still out of use. }\end{array}$ & M \\
\hline Connection between rail trails and non-motorised routes of similar characteristics. & $\mathrm{H}$ \\
\hline Inclusion of the trails in national or international networks of routes. & $\mathrm{H}$ \\
\hline $\begin{array}{l}\text { Boost enterprise and job creation through the introduction and expansion of } \\
\text { services and economic activities linked to tourism. }\end{array}$ & $\mathrm{H}$ \\
\hline $\begin{array}{l}\text { Increase the possibilities of socio-economic revitalisation of municipalities } \\
\text { affected by the trails. }\end{array}$ & $\mathrm{H}$ \\
\hline $\begin{array}{l}\text { Creation of effective channels of dissemination on the use and exploitation of } \\
\text { the trails. }\end{array}$ & M \\
\hline Deseasonalisation of tourism activity in the area of influence of the trails. & M \\
\hline Diversification of local economies & M \\
\hline Increase in local incomes. & $\mathrm{L}$ \\
\hline $\begin{array}{l}\text { Growing trend towards greater contact with nature and with landscapes that have } \\
\text { a unique appeal. }\end{array}$ & $\mathrm{H}$ \\
\hline $\begin{array}{l}\text { Increased number of users of the trails through the use of Information and } \\
\text { Communication Technologies. }\end{array}$ & M \\
\hline Promotion of the "Rail Trail" tourism product. & $\mathrm{M}$ \\
\hline $\begin{array}{l}\text { Improve public use of the trails by means of a user management and guidance } \\
\text { plan or programme. }\end{array}$ & M \\
\hline
\end{tabular}




\begin{tabular}{|c|c|}
\hline $\begin{array}{l}\text { Increase public knowledge of the history and impact of railway lines prior to the } \\
\text { rail trails. }\end{array}$ & M \\
\hline $\begin{array}{l}\text { Increase user knowledge of resources and values of the municipalities that the } \\
\text { trails pass through. }\end{array}$ & M \\
\hline $\begin{array}{l}\text { Possibility of creation of a body at regional level to coordinate the management } \\
\text { and promotion of Andalusianrail trails. }\end{array}$ & M \\
\hline Threats & Recurrence* \\
\hline $\begin{array}{l}\text { User confusion and/or dissolution of the synergies to different levels (local, } \\
\text { regional, national) due to the lack of a clear identity of the rail trails. }\end{array}$ & M \\
\hline $\begin{array}{l}\text { Diminished appeal of the trails in view of the present diversity of non-motorised } \\
\text { routes. }\end{array}$ & $\mathrm{L}$ \\
\hline $\begin{array}{l}\text { Remaining outside the visibility provided by the major cycle tourism routes and/ } \\
\text { or non-motorised routes at national and international level. }\end{array}$ & $\mathrm{L}$ \\
\hline $\begin{array}{l}\text { Lack of coordination or lack of commitment between administrations for their } \\
\text { promotion and management. }\end{array}$ & $\mathrm{L}$ \\
\hline $\begin{array}{l}\text { High level of dispersion and lack of loyalty of tourism demand (national and/or } \\
\text { international). }\end{array}$ & $\mathrm{L}$ \\
\hline Dismantling of the rail trail network in Andalusia. & $\mathrm{M}$ \\
\hline $\begin{array}{l}\text { High level of competency for these non-motorised routes of other territories } \\
\text { (other neighbouring regions or countries, and even within Andalusia itself). }\end{array}$ & $\mathrm{L}$ \\
\hline $\begin{array}{l}\text { Scant allocation of economic, technical and human resources in the policy of } \\
\text { promoting rail trails in Andalusia. }\end{array}$ & $\mathrm{H}$ \\
\hline $\begin{array}{l}\text { Little presence (or consideration) of the rail trails in the products offered by } \\
\text { operators and other agents of tourism intermediation. }\end{array}$ & M \\
\hline $\begin{array}{l}\text { The exploitation of these routes is influenced by meteorological conditions, as } \\
\text { they are outdoor activities. }\end{array}$ & M \\
\hline $\begin{array}{l}\text { Lack of coordination or lack of commitment between administrations for their } \\
\text { promotion and management. }\end{array}$ & M \\
\hline $\begin{array}{l}\text { Diversity of realities with regard to the concept of non-motorised routes in the } \\
\text { international context, making it difficult to adapt the rail trail offer to a market or } \\
\text { user profile compatible with the product created. }\end{array}$ & $\mathrm{L}$ \\
\hline $\begin{array}{l}\text { Persistence of effects of the economic-financial crisis on flow of tourists to these } \\
\text { trails. }\end{array}$ & $\mathrm{L}$ \\
\hline Excessive competition from cycle tourism destinations outside Andalusia. & $\mathrm{L}$ \\
\hline External cycle tourists' negative perception of Andalusia's rail trail offer. & $\mathrm{L}$ \\
\hline $\begin{array}{l}\text { Dependence on external aid to maintain trails and/or promotion of tourism } \\
\text { initiatives. }\end{array}$ & $\mathrm{L}$ \\
\hline
\end{tabular}

* Level of recurrence of the replies: Low (L); Medium (M); High (H). 